\title{
Generation of Powerful Human Tolerogenic Dendritic Cells by Lentiviral-Mediated IL-10 Gene Transfer
}

\begin{abstract}
Michela Comi, Giada Amodio, Laura Passeri, Marta Fortunato, Francesca Romana Santoni de Sio, Grazia Andolfi, Anna Kajaste-Rudnitski, Fabio Russo, Luca Cesana and Silvia Gregori*
\end{abstract}

San Raffaele Telethon Institute for Gene Therapy (SR-TIGET), San Raffaele Scientific Institute (IRCCS), Milan, Italy

The prominent role of dendritic cells (DC) in promoting tolerance and the development of methods to generate clinical grade products allowed the clinical application of tolerogenic DC (toIDC)-based therapies for controlling unwanted immune responses. We established an efficient method to generate tolerogenic human DC, producing supra-physiological levels of IL-10, by genetically engineering monocyte-derived DC with a bidirectional Lentiviral Vector (bdLV) encoding for $\mathrm{LL}-10$ and a marker gene. $\mathrm{DC} \mathrm{L}^{\mathrm{L}-10}$ are mature $\mathrm{DC}$, modulate $\mathrm{T}$ cell responses, promote $\mathrm{T}$ regulatory cells, and are phenotypically and functionally stable upon stimulation. Adoptive transfer of human $\mathrm{DC}^{\mathrm{lL}-10}$ in a humanized mouse model dampens allogeneic T cell recall responses, while murine $\mathrm{DC} \mathrm{C}^{\mathrm{L}-10}$ delays acute graft-vs.-host disease in mice. Our report outlines an efficient method to transduce human myeloid cells with large-size LV and shows that stable over-expression of IL-10 generates an effective cell product for future clinical applications in the contest of allogeneic transplantation.

Keywords: dendritic cells, IL-10, cell therapy, immune tolerance, allogeneic transplantation

\section{INTRODUCTION}

Tolerogenic dendritic cells (tolDC) are characterized by low expression of costimulatory molecules, upregulation of inhibitory, and/or modulatory receptors, secretion of low amounts of pro-inflammatory, and high levels of anti-inflammatory cytokines (1). All these factors are responsible for the regulatory capacity of tolDC, which results in the inhibition of effector $\mathrm{T}$ cell responses and the induction of $\mathrm{T}$ regulatory cells (Tregs) (2). This ability to control immune responses and promote tolerance makes tolDC an interesting candidate for cell therapy approaches in transplantation and in autoimmunity. The seminal study that led to the use of tolDC as inhibitors of allograft rejection stemmed from data demonstrating that adoptive transfer of donor-derived tolDC prolonged heart or pancreatic islet graft survival in mice $(3,4)$. Since then, several studies in pre-clinical models of transplantation using cells of donor or host origin demonstrated the regulatory capacity of tolDC (1,5-7). Clinical trials using tolDC to prevent rejection after liver or kidney transplantation (8) (ClinicalTrials.gov identifier: NCT02252055; NCT03726307; NCT03164265), or to restore tolerance in patients with autoimmune diseases, such as rheumatoid arthritis, type 1 diabetes, multiple sclerosis, and Crohn's disease (9-13) have been completed or are ongoing. 
TolDC can be differentiated in vitro by treatment with immunosuppressive compounds, anti-inflammatory cytokines, or by genetic modifications (14-16). Among the different approaches used for inducing tolDC, IL-10 has been shown to potently modulate the differentiation and functions of myeloid cells (17), leading to the generation of the tolDC with the most powerful tolerogenic characteristics (18).

In the present study, we genetically engineered monocytes prior to DC differentiation with a bidirectional Lentiviral Vector (bdLV) encoding for IL-10 and a marker gene ( $\triangle$ NGFR). Human myeloid cells are resistant to HIV-1 infection, thus to bdLV transduction. One of the restriction factors mediating this resistance is SAMHD1 $(19,20)$, which depletes the cytoplasmic pool of deoxynucleoside triphosphates, affecting the reverse transcription process (21). Vpx protein from simian immunodeficiency viruses directs proteasome-mediated degradation of SAMHD1 (22), restoring HIV-1 infection in myeloid cells $(19,20,23,24)$. Therefore, we exploited this natural inhibitor of SAMHD1, treating the monocytes with Vpx-containing viral like particles for $6 \mathrm{~h}$ before bdLV transduction $(25,26)$, and reached up to $98 \%$ of transduced monocyte-derived DC. We evaluated the immunotherapeutic role of tolDC generated by bdLV-mediated IL-10 overexpression $\left(\mathrm{DC}^{\mathrm{IL}-10}\right)$ in the context of allogeneic tolerance induction. We delineated the phenotype and cytokine profile of $\mathrm{DC}^{\mathrm{IL}-10}$, we defined their stability upon inflammatory signal exposure, and we analyzed their functionality both in vitro and in vivo. We also assessed $\mathrm{DC}^{\mathrm{IL}-10}$ activity in vivo and showed that adoptive $\mathrm{DC}^{\mathrm{IL}-10}$ transfer in humanized mice reduced the allogeneic response in antigen-specific manner, and treatment of allogeneic transplanted mice with $\mathrm{DC}^{\mathrm{IL}-10}$ autologous to the recipient delayed acute GvHD, prolonging mice survival.

\section{MATERIALS AND METHODS}

\section{Vector Production and Titration}

VSV-G-pseudotyped third generation bidirectional Lentiviral Vectors (bdLV) were produced by calcium phosphate transfection into $293 \mathrm{~T}$ cells and concentrated by ultracentrifugation as described previously (27). Titer was estimated by limiting dilution: vector particles were measured by HIV-1 Gag p24 Ag immune capture (NEN Life Science Products, MA, USA), and vector infectivity was calculated as the ratio between titer and total particles. Titers ranged between $5 \times 10^{8}$ and $6 \times 10^{9}$ transducing units $/ \mathrm{mL}$, while infectivity between $5 \times 10^{4}$ and $10^{5}$ transducing units/ng p24. To produce concentrated Vpx-incorporating viral-like particles (VLPs), 293T cells were co-transfected with a VSV-g expressing plasmid and the Simian Immunodeficiency Virus-derived packaging plasmid SIV3+, as previously described (26). For bioluminescence imaging (BLI), luciferase-encoding cDNA was cloned into in LV-GFP instead of the GFP gene and into LV-IL10 instead of $\triangle$ NGFR gene to allow in vivo tracking of transduced murine $\mathrm{DC}$ ( $\mathrm{DC}^{\mathrm{NGFR}}$ and $\mathrm{DC}^{\mathrm{IL}-10}$, respectively).

\section{Peripheral Blood Mononuclear Cell (PBMC) Isolation}

Human peripheral blood was obtained from healthy donors in accordance with local committee approval (TIGET09), and with the Declaration of Helsinki. Peripheral blood mononuclear cells were isolated by density gradient centrifugation over Lymphoprep $^{\text {TM }}$ (Axis-Shield PoC AS, Norway).

\section{Human Dendritic Cells}

$\mathrm{CD}_{14}{ }^{+}$cells were isolated from $\mathrm{PBMC}$ by positive selection using CD14 MicroBeads (Miltenyi Biotech, Germany) according to the manufacturer's instructions. Cells were cultured in RPMI 1640 (Lonza, Switzerland) with 10\% fetal bovine serum (FBS) (Euroclone, Italy), $100 \mathrm{U} / \mathrm{ml}$ penicillin/streptomycin (Lonza, Switzerland), $2 \mathrm{mM}$ L-glutamine (Lonza, Switzerland), at $10^{6}$ cells $/ \mathrm{ml}$ in a $1 \mathrm{ml}$ volume in a 24-well culture plate, supplemented with rhGM-CSF (Miltenyi Biotech, Germany) at $100 \mathrm{ng} / \mathrm{ml}$ and rhIL-4 (Miltenyi Biotech, Germany) at $10 \mathrm{ng} / \mathrm{ml}$ for 7 days at $37^{\circ} \mathrm{C}$ with $5 \% \mathrm{CO}_{2}$. One $\mathrm{ml}$ per well of fresh pre-warmed medium with cytokines, at final concentration as above, was added on day 3. To obtain mature $\mathrm{DC}(\mathrm{mDC})$, un-transduced $\mathrm{DC}$ were activated at day 5 with $1 \mu \mathrm{g} / \mathrm{ml}$ of LPS (Sigma Aldrich, CA, USA). For DC transduction, monocytes were exposed for $6 \mathrm{~h}$ to $\mathrm{Vpx}-\mathrm{VLP}$ and then were transduced with the indicated vectors at Multiplicity of Infection (MOI) of 5 at day 0, 2, or 5. After overnight incubation, half of the medium was replaced with fresh medium supplemented with cytokines to dilute the vector concentration. For $\mathrm{DC}^{\mathrm{IL}-10}$ generation, $10 \mathrm{ng} / \mathrm{ml}$ of $\mathrm{rhIL}-10$ (CellGenix, Germany) was added at day 0. In some experiments, $\mathrm{DC}^{\mathrm{IL}-10}$ were activated at day 6 with $1 \mu \mathrm{g} / \mathrm{ml}$ of LPS (Sigma Aldrich, CA, USA) or with $10 \mu \mathrm{g} / \mathrm{ml}$ of Poli (I:C) (InvivoGen, CA, USA). DC were harvested on day 7 for phenotypical, molecular, and functional analyses.

In some experiments, $10^{5} \mathrm{DC}$ were plated in $200 \mu \mathrm{l}$ of final volume, alone or in the presence of the following stimulation: $1 \mu \mathrm{g} / \mathrm{ml}$ of LPS (Sigma Aldrich, CA, USA), $10^{8}$ cells $/ \mathrm{ml}$ of Heat Killed Listeria Monocytogenes, $1 \mu \mathrm{g} / \mathrm{ml}$ of Flagellin $S$. typhimurium, $10 \mu \mathrm{g} / \mathrm{ml}$ of Poli (I:C), $5 \mu \mathrm{M}$ of ODN2006 (CpG) (InvivoGen, CA, USA) or a mix of $10 \mathrm{ng} / \mathrm{ml}$ for each cytokine of IL- $1 \beta$, TNF- $\alpha$, and IL-6 (R\&D Systems, MN, USA). After $24 \mathrm{~h}$, supernatants were collected to evaluate the cytokine secretion profile by ELISA, and cells were analyzed by flow cytometry.

\section{Human T Cells}

$\mathrm{CD}^{+}, \mathrm{CD}^{+}$, and $\mathrm{CD}^{+} \mathrm{T}$ cells were purified from PBMC by negative selection using their respective human $\mathrm{T}$ cell Isolation kit (Miltenyi Biotech, Germany) according to the manufacturer's instructions. All T cell cultures were performed in X-VIVO 15 medium (Lonza, Switzerland), supplemented with $5 \%$ human serum (Sigma Aldrich, CA, USA), and $100 \mathrm{U} / \mathrm{ml}$ penicillin/streptomycin (Lonza, Switzerland). T cells were labeled with Cell Proliferation Dye eFluor ${ }^{\circledR} 670$ (eBioscience, CA, USA) according to manufacturer's instructions and stimulated with $10^{4}$ allogeneic DC (10:1, T:DC). After 5 days, T cells were collected, washed, and their phenotype and proliferation were analyzed by flow cytometry. 
For $\mathrm{T}$ cell differentiation, $10^{6} \mathrm{CD}^{+} \mathrm{T}$ cells were cultured with $10^{5}$ allogeneic DC (10:1, T:DC). After 10 days, primed T cells were collected and purified using CD4 Microbeads (Miltenyi Biotech, Germany). T cells stimulated with $\mathrm{DC}^{\mathrm{UT}}$ are referred to as $\mathrm{T}\left(\mathrm{DC} \mathrm{C}^{\mathrm{UT}}\right)$ cells, while those stimulated with $\mathrm{DC}^{\mathrm{GFP}}$ as $\mathrm{T}\left(\mathrm{DC} \mathrm{CFP}^{\mathrm{GF}}\right)$ cells. T cells cultured with unstimulated $\mathrm{DC}^{\mathrm{IL}-10}$ are referred to as $\mathrm{T}\left(\mathrm{DC}^{\mathrm{IL}-10}\right)$ cells, while those cultured with LPS- or Poli I:C-stimulated $\mathrm{DC}^{\mathrm{IL}-10}$ are referred to as T(DC $\left.\mathrm{DC}^{\mathrm{IL}-10-\mathrm{LPS}}\right)$ or $\mathrm{T}\left(\mathrm{DC}^{\mathrm{IL}-10-\mathrm{POLI}}\right)$ cells, respectively.

For recall response proliferation, primed $\mathrm{CD} 4^{+} \mathrm{T}$ cells were stained with Cell Proliferation Dye eFluor ${ }^{\circledR} 670$ (eBioscience, CA, USA) and plated with DC ${ }^{\mathrm{UT}}$ from the same donor used for priming (10:1, T:DC). After 3 days of stimulation, $\mathrm{T}$ cells were collected, washed, and proliferation was evaluated by flow cytometry.

To evaluate the suppressive activity of $\mathrm{T}\left(\mathrm{DC} \mathrm{C}^{\mathrm{IL}-10}\right)$, $\mathrm{T}\left(\mathrm{DC}^{\mathrm{IL}-10-\mathrm{LPS}}\right)$, or $\mathrm{T}\left(\mathrm{DC}^{\mathrm{IL}-10-\mathrm{POLI}}\right)$ cells, we stained total $\mathrm{CD}^{+} \mathrm{T}$ cells (responder cells) autologous to $\mathrm{T}$ cells used in priming with Cell Proliferation Dye eFluor ${ }^{\circledR} 450$ (eBioscience, CA, USA), and activated them with $\mathrm{mDC}$ from the same donor used for priming. $\mathrm{T}\left(\mathrm{DC}^{\mathrm{IL}-10}\right), \mathrm{T}\left(\mathrm{DC} \mathrm{C}^{\mathrm{IL}-10-\mathrm{LPS}}\right)$, or $\mathrm{T}\left(\mathrm{DC}^{\mathrm{IL}-10-\mathrm{POLI}}\right)$ cells stained with Cell Proliferation Dye eFluor $^{\circledR} 670$ (eBioscience, CA, USA), were added at a 1:1 ratio with responder cells (total T:DC ratio is 10:1). After 4 days, the percentages of divided responder $\mathrm{T}$ cells were calculated by proliferation dye dilution by flow cytometer.

\section{Cytokine Determination}

For DC, the indicated number of cells were plated in $200 \mu \mathrm{l}$ of final volume and left unstimulated or activated with $200 \mathrm{ng} / \mathrm{ml}$ of LPS (Sigma, CA, USA) and $50 \mathrm{ng} / \mathrm{ml}$ of IFN- $\gamma$ (R\&D System, MN, USA). Supernatants were collected after $48 \mathrm{~h}$ and levels of IL-6, IL-10, IL-12, and TNF- $\alpha$ were tested.

For $\mathrm{CD}^{+} \mathrm{T}$ cells, IL-10, and IFN- $\gamma$ production was quantified in co-culture supernatants. Cytokine concentration was evaluated by standard sandwich ELISA, with purified and biotinylated antibody couples (Becton Dickinson, CA, USA).

\section{Mice}

NSG, Balb/c and C57Bl/6 female mice were purchased from Charles-River Italia. All mice were fed standard laboratory diet and maintained under standard laboratory conditions free of specific pathogens. All animal care procedures were performed according to protocols approved by the OSR Institutional Animal Care and Use Committee (IACUC protocol \#488, \#632, and $\# 748$ ), following the $3 \mathrm{R}$ principles (replacement, reduction, and refinement) and the Decreto Legislativo \#116 dated January 27th, 1992, from the Italian Parliament.

\section{Modulation of Immune Response in Humanized Mice}

Two-five days old NSG (NOD.Cg-PrkDC ${ }^{\text {cid }} \mathrm{Il}_{\mathrm{rg}}{ }^{\mathrm{tm} 1} \mathrm{WjI} / \mathrm{SzJ}$, JAX mouse strain) mice were sub-lethally irradiated (1.5cGy) and injected intra-hepatically $5-7 \mathrm{~h}$ later with $10^{5} \mathrm{CD}^{+} 4^{+}$ (purity $\geq 95 \%$, Lonza), as previously described (28). Percentages of human cells in peripheral blood were monitored by flow cytometry starting from 8 weeks post-transplant. Once human engraftment was stable and $\mathrm{T}$ cell repopulation detectable (usually around 11-13 weeks post-transplant), humanized mice (huMice) were immunized by intravenous injection (i.v.) of 5 $\times 10^{6}$ irradiated allogeneic $\mathrm{CD}^{-}$cells $(6,000 \mathrm{rad})$, magnetically isolated with Dynabeads CD3 (Thermo Fisher Scientific, MA, USA) from human PBMC. One week later, human $\mathrm{T}$ cell percentages were assessed by flow cytometry, huMice were randomly assigned to experimental groups and injected with $3 \times 10^{5}$ un-transduced DC, or $3 \times 10^{5}$ un-transduced plus $3 \times 10^{5}$ transduced DC, differentiated from CD14 ${ }^{+}$ monocytes isolated from the same donor used for $\mathrm{CD}^{-}$ purification. After peripheral blood phenotyping at day 10 and 13, huMice were suppressed at day 13 and peripheral blood harvested.

\section{Murine DC Differentiation and Transduction}

Female Balb/c mice were sacrificed and bone marrow (BM) was harvested. BM cells were cultured in IMDM (Lonza, Switzerland) with $10 \%$ fetal bovine serum (FBS) (Euroclone, Italy), $100 \mathrm{U} / \mathrm{ml}$ penicillin/streptomycin (Lonza, Switzerland), $2 \mathrm{mM}$ L-glutamine (Lonza, Switzerland), at $10^{6}$ cells $/ \mathrm{ml}$ in a $1 \mathrm{ml}$ volume in a 24 -well culture plate, supplemented with rmGM-CSF (R\&D Systems, $\mathrm{MN}, \mathrm{USA}$ ) at $25 \mathrm{ng} / \mathrm{ml}$ for 9 days at $37^{\circ} \mathrm{C}$ with $5 \% \mathrm{CO}_{2}$. One $\mathrm{ml}$ per well of fresh pre-warmed medium with rmGM-CSF, at final concentration as above, was added on day 3 and, after removal of $1 \mathrm{ml}$ of supernatant from the culture, at day 5. DC were activated at day 7 with $200 \mathrm{ng} / \mathrm{ml}$ of LPS (Sigma Aldrich, CA, USA). For $\mathrm{DC}$ transduction, cells were transduced with indicated vectors at MOI of 10 at day 2 .

\section{Splenocyte Stimulation}

Spleen mononuclear cells were isolated from female C57Bl/6 (H-2b) mice and stained with Proliferation Dye eFluor ${ }^{\circledR} 670$ (eBioscience, CA, USA). $10^{5}$ splenocytes were plated with $10^{4}$ $\mathrm{DC}^{\mathrm{GFP}}$ or $\mathrm{DC}^{\mathrm{IL}-10}$ differentiated from $\mathrm{BM}$ of female Balb/c mice and collected after 5 days to assess the proliferation by dye dilution.

\section{Bioluminescence Image Acquisition and Analysis}

Female Balb/c (H-2d) mice were lethally irradiated (10 Gy) and intravenously injected with $2 \times 10^{6} \mathrm{DC}^{\mathrm{NGFR}}$ or $\mathrm{DC}^{\mathrm{IL}-10}$, with or without the addition of $10^{7} \mathrm{Balb} / \mathrm{c}$ (H-2d) BM cells. Smallanimal bioluminescence imaging (BLI) was performed using the IVIS Spectrum CT System (Perkin Elmer). The system is composed of a low-noise, back-thinned, back-illuminated charge-coupled device (CCD) camera cooled at $-90^{\circ} \mathrm{C}$ with a quantum efficiency in the visible range above $85 \%$. Each mouse received an intravenous injection of $150 \mathrm{mg}$ luciferin $/ \mathrm{kg}$ body weight $10 \mathrm{~min}$ before BLI. During image acquisition, the animals were kept at $37^{\circ} \mathrm{C}$ and under gaseous anesthesia $(2-3 \%$ isoflurane and $1 \mathrm{~L} / \mathrm{min}$ oxygen). Dynamic BLI was performed by acquiring a set of images every $2 \mathrm{~min}$ from 10 to $20 \mathrm{~min}$ after luciferin injection to detect the highest BLI signal. The images were obtained using the following settings: exposure time $=$ 
auto, binning $=8$, and field of view $=23.4 \mathrm{~cm}$. Dark images were acquired before and then subtracted to bioluminescence images; no emission filters were used during BLI acquisitions. BLI image analysis was performed by placing a region of interest (ROI) over the body of the mouse (tail excluded) and by measuring the total flux (photons/seconds) within the ROI. Images were acquired and analyzed using Living Image 4.5 (Perkin Elmer).

\section{In vivo Acute Graft vs. Host Disease Model}

Acute graft vs. host disease (GvHD) was induced by a single intravenous injection of $\mathrm{BM}$ cells $\left(10 \times 10^{6}\right)$ supplemented with $5 \times 10^{6}$ spleen mononuclear cells isolated from female $\mathrm{C} 57 \mathrm{Bl} / 6$ (H-2b) mice into recipient female Balb/c (H-2d) mice lethally irradiated ( $10 \mathrm{~Gy}$ total body irradiation). Recipients received single intravenous injections of host-matched $\mathrm{DC}^{\mathrm{GFP}}$ or $\mathrm{DC}^{\mathrm{IL}-10}\left(2 \times 10^{6}\right) 3$ days after transplantation. Recipients were monitored once every other day from the day of transplantation to determine survival time, body weight and score (fur, hunch, skin lesion, mobility). Moribund mice were euthanized for ethical reason (more than $25 \%$ of weight loss or score higher than six).

\section{Flow Cytometry}

Fluorochrome-conjugated antibodies against the following antigens were used for human DC staining: NGFR, CD1a, CD14, CD83, CD86, HLA-DR, CD16, CD163 (Becton Dickinson, CA, USA), and CD141 (Miltenyi Biotech, Germany), HLA-G (Exbio, Czech Republic), ILT4 (Beckman Counter, NJ, USA). The following fluorochrome-conjugated antibodies were used for human $\mathrm{CD}^{+}{ }^{+} \mathrm{T}$ cell staining: anti-CD3, anti-CD4, anti-CD8, and anti-CD45RA (Becton Dickinson, CA, USA), anti-CD49b and anti-LAG-3 (Miltenyi Biotec, Germany). For Tr1 cell detection, $\mathrm{CD}^{+}{ }^{+} \mathrm{T}$ cells were stained as previously described (29).

Fluorochrome-conjugated antibodies against the following antigens were used for murine DC staining: NGFR, CD11c, CD80, CD83, CD86, I-A/I-E (Becton Dickinson, CA, USA). The following fluorochrome-conjugated antibodies were used for murine splenocyte staining: anti-CD3, anti-CD4, and anti-CD8 (Becton Dickinson, CA, USA).

FcR Blocking Reagent (Miltenyi Biotech, Germany for human sample and Becton Dickinson, CA, USA for mice samples) was used in all preparations to avoid non-specific staining. Briefly, cells were centrifuged and re-suspended in Dulbecco's Phosphate-Buffered Saline (DPBS, Corning) supplemented with 2\% FBS (Lonza, Switzerland). Cells were incubated at room temperature for $15 \mathrm{~min}$, centrifuged and fixed with $1 \%$ formaldehyde solution methanol-free (Thermo Fisher Scientific, MA, USA). For cultured cells, the described passages where preceded by staining with LIVE/DEAD ${ }^{\mathrm{TM}}$ Fixable Dead Cell Stain Kit (Invitrogen, CA, USA) following manufacturer's instructions.

For huMice blood staining, $100 \mu \mathrm{l}$ of whole blood was stained with antibodies against surface markers for $15 \mathrm{~min}$ at room temperature. Cells were then fixed, permeabilized and stained with anti-KI67 (Becton Dickinson, CA, USA) using Foxp3/Transcription Factor Staining Buffer Set (eBioscience, USA). Samples were acquired using the FACSCanto II or Fortessa
Flow Cytometers (Becton Dickinson, CA, USA) and data were analyzed with FlowJo software (FlowJo LLC, USA).

\section{Statistical Analysis}

Wilcoxon matched pairs test (two-tailed) were used for statistical analysis. All results are presented as mean values \pm standard deviation, unless differently specified in the figure legend. Differences were regarded as significant at ${ }^{*} P \leq 0.05,{ }^{* *} P \leq 0.01$, and ${ }^{* * *} P \leq 0.001$. Results were analyzed using GraphPad Prism 5.0 (GraphPad Software, CA, USA).

\section{RESULTS}

\section{Monocytes Can Be Stably and Highly Transduced With Bidirectional Lentiviral Vectors}

Lentiviral vector (LV) transduction of monocyte-derived DC has been described; however, transduction efficiency is generally low due to the inhibition of reverse transcription in human myeloid cells mediated by SAMHD1 $(19,20,23)$. The use of polybrene in combination with simian immunodeficiency virus (SIV)derived accessory protein Vpx during LV transduction has been proposed to overcome this limitation $(26,30)$. We optimized the transduction protocol of human monocyte-derived DC with LV encoding large size plasmid $(\sim 10 \mathrm{~kb})$, by pre-treating $\mathrm{CD} 14^{+}$ cells with viral-like particles containing Vpx (Vpx-VLP) in the absence of polybrene before exposure to a bdLV co-encoding for GFP and $\triangle$ NGFR (LV-GFP). CD14 ${ }^{+}$cells were pre-treated or not with Vpx-VLP for $6 \mathrm{~h}$ on day 0,2 , or 5 before LVGFP exposure during monocyte-derived DC differentiation, and transduction efficiency was evaluated at the end of differentiation (Figure S1A). Pre-treatment with Vpx-VLP at all time points analyzed improved transduction, reaching the highest efficiency when cells were pre-treated with Vpx-VLP at day 0 (up to $95 \%$ of $\triangle \mathrm{NGFR}^{+} \mathrm{DC}$, Figure S1B). As expected, in the absence of Vpx-VLP, DC were transduced at very low levels $(<6 \%$ of $\triangle \mathrm{NGFR}^{+} \mathrm{DC}$ ), irrespectively of the day of transduction (Figure S1B). We then applied the above protocol to transduce CD14 ${ }^{+}$cells with a bdLV co-encoding for IL-10 and $\triangle$ NGFR (LV-IL-10) (31). Although the transduction efficiency of DC $\mathrm{CL}^{\mathrm{IL}-10}$ was similar to that of DC ${ }^{\mathrm{GFP}}$ (not shown), the differentiated population contained two distinct cell subtypes $\left(\mathrm{CD} 14^{-} \mathrm{CD} 16^{-}\right.$ and $\mathrm{CD}_{14}{ }^{+} \mathrm{CD} 16^{+}$; Figure S1C). Since the presence of IL-10 from day 0 of differentiation results in high CD14 and CD16 expression in DC-10 (32), we hypothesized that the observed heterogenicity in $\mathrm{DC}^{\mathrm{IL}-10}$ was due to a later exposure to IL-10. For this reason, we added exogenous IL-10 at day 0 during $\mathrm{CD}_{14}{ }^{+}$cell pre-treatment with Vpx-VLP and exposure to LV-IL-10 (Figure 1A) and we obtained a homogenous population of $\mathrm{CD}_{1}{ }^{+} \mathrm{CD} 16^{+} \mathrm{DC}^{\mathrm{IL}-10}$ (Figure S1C), with an average transduction efficiency of $90 \%$ for $\mathrm{DC}^{\mathrm{IL}-10}$, which was superimposable to that of DC ${ }^{\mathrm{GFP}}$ (Figure 1B). In conclusion, we established an efficient protocol to transduce human monocytes during DC differentiation with large-size LV. 


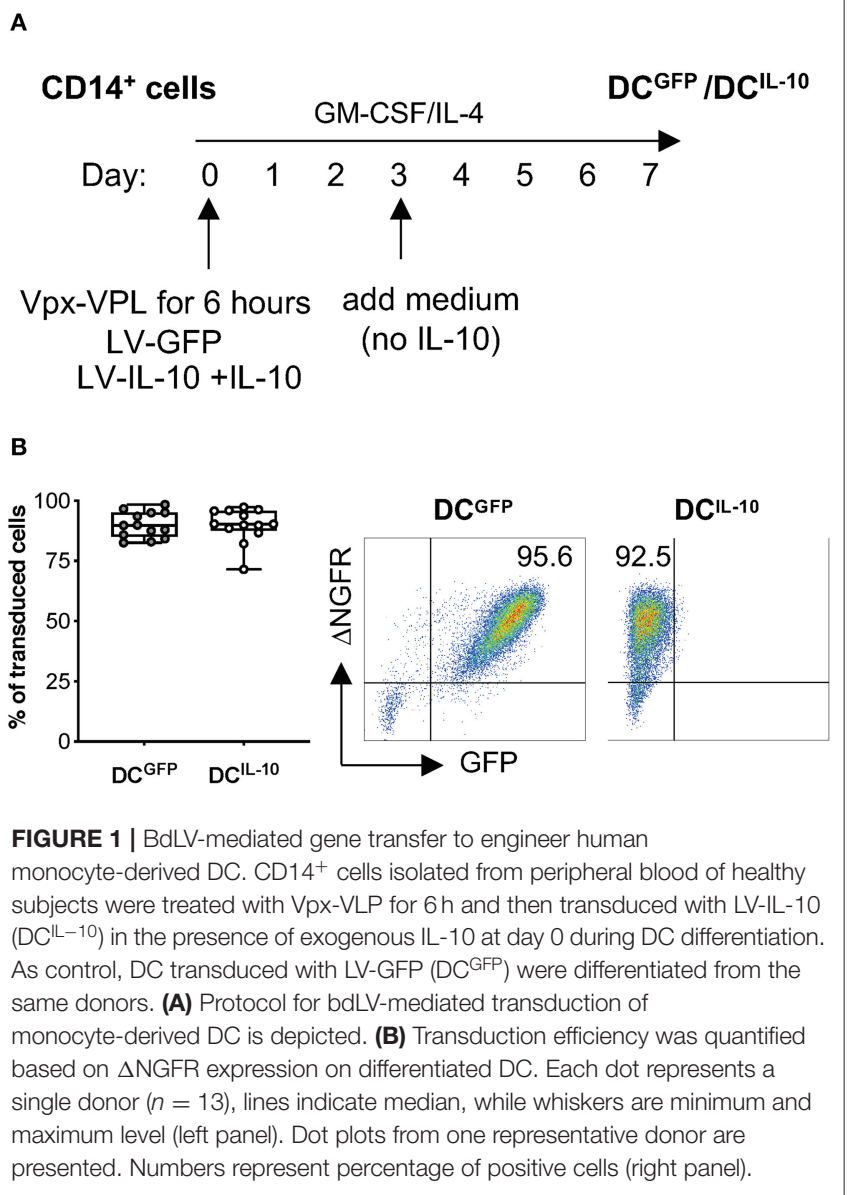

\section{Human DC ${ }^{\mathrm{IL}-10}$ Express DC-10-Associated Markers and Secrete Supra-Physiological Levels of IL-10}

We previously described a subset of human DC, called DC-10, that are differentiated in vitro through exposure of monocytes to IL-10 during DC differentiation (32) and, recently, we identified DC-10-specific biomarkers (33). Since DC ${ }^{\mathrm{IL}-10}$ are differentiated in the presence of IL-10, it was not surprising that they expressed the DC-10 markers CD14, CD16, CD141, and CD163 at significantly higher levels compared to un-transduced ( $\mathrm{DC}^{\mathrm{UT}}$ ) and LV-GFP transduced (DC ${ }^{\text {GFP }}$ ) cells, while the levels of CD1a, marker of the classical monocyte-derived DC, were significantly lower (Figure 2A). We next evaluated the expression of MHC class II and costimulatory molecules, important for appropriate antigen presentation to and activation of $\mathrm{T}$ cells. In all donors tested, HLA-DR expression in DC ${ }^{\mathrm{IL}-10}$ was significantly higher than in $\mathrm{DC}^{\mathrm{UT}}$ and DC ${ }^{\mathrm{GFP}}$, while the expression of CD83 and CD86 on DC ${ }^{\mathrm{IL}-10}$ was variable among donors tested, with some donors showing higher and others similar expression levels compare to control DC (Figure 2B). The levels of the tolerogenic molecules HLA-G and ILT4, known to be required for $\mathrm{T}$ regulatory type $1(\mathrm{Tr} 1)$ cell induction via DC-10 (32), were significantly higher on $\mathrm{DC}^{\mathrm{IL}-10}$ compared to control DC (Figure 2C).

As expected, DC ${ }^{\mathrm{IL}-10}$ secreted high amounts of IL-10 at steady state and upon LPS/IFN- $\gamma$ stimulation, in the absence of IL-12. Conversely, stimulated DC ${ }^{\mathrm{UT}}$ and DC ${ }^{\mathrm{GFP}}$ produced high levels of IL-12 and variable levels of IL-10, always lower compared to that of $\mathrm{DC}^{\mathrm{IL}-10}$. There were no differences in the secretion of IL-6 upon stimulation, while higher IL-6 secretion in $\mathrm{DC}^{\mathrm{IL}-10}$ compared to $\mathrm{DC}^{\mathrm{UT}}$ at steady state was detected. TNF- $\alpha$ release was not observed in the absence of stimulation, whereas the lowest levels of TNF- $\alpha$ were measured in stimulated DC ${ }^{\mathrm{IL}-10}$ compared to controls (Figure 3). Overall, DC $^{\mathrm{IL}-10}$ showed a high IL-10/TNF- $\alpha$ and IL-10/IL-12 ratio indicative of their skewing toward tolerance, opposite to the pro-inflammatory cytokine profile displayed by $\mathrm{DC}^{\mathrm{UT}}$ and $D^{\mathrm{GFP}}$. Altogether, our results show that stable and enforced expression of IL-10 in human monocyte-derived DC through bdLV-mediated gene transfer promotes the differentiation of mature tolerogenic DC-10-like cells, which express HLA-G and ILT4.

\section{Human DC'L-10 Modulate Allogeneic T Cell Responses and Promote Allo-Specific Tr1 Cells in vitro}

We then proceeded to the functional characterization of $\mathrm{DC}^{\mathrm{IL}-10}$ and found that they induced significantly lower proliferative responses in allogeneic $\mathrm{CD}^{+} \mathrm{T}$ cells when compared to that elicited by control $\mathrm{DC}^{\mathrm{UT}}$ and $\mathrm{DC}^{\mathrm{GFP}}$, in both $\mathrm{CD} 4^{+}$ and $\mathrm{CD}^{+} \mathrm{T}$ cells (Figure 4A). According to their similarity to DC-10 and their ability to secrete high levels of IL-10, stimulation of allogeneic $\mathrm{CD} 4^{+} \mathrm{T}$ cells with $\mathrm{DC}^{\mathrm{IL}-10}$ allowed the differentiation of cells- $\mathrm{T}\left(\mathrm{DC} \mathrm{C}^{\mathrm{IL}-10}\right)$ cells-that contained a significantly higher proportion of $\mathrm{Tr} 1$ cells compared to $\mathrm{T}$ cells primed with $\mathrm{DC}^{\mathrm{UT}}$ and $\mathrm{DC}^{\mathrm{GFP}}-\mathrm{T}\left(\mathrm{DC}^{\mathrm{UT}}\right)$ and $\mathrm{T}\left(\mathrm{DC}^{\mathrm{GFP}}\right)$ cells, respectively-(Figure 4B). In line with the presence of $\operatorname{Tr} 1$ cells, $\mathrm{T}\left(\mathrm{DC} \mathrm{IL}^{\mathrm{L}-10}\right)$ cells re-stimulated with mature $\mathrm{DC}$ $(\mathrm{mDC})$, autologous to DC used for priming, were hyporesponsive (Figure 4C), and produced significantly higher level of IL-10, but similar levels of IFN- $\gamma$ compared to both $\mathrm{T}\left(\mathrm{DC}^{\mathrm{UT}}\right)$ and $\mathrm{T}\left(\mathrm{DC}^{\mathrm{GFP}}\right)$ cells (Figure $\left.4 \mathrm{D}\right)$. Notably, anergy was alloantigen-specific, since the stimulation with a third party $\mathrm{mDC}$ induced comparable levels of proliferation in all primed $\mathrm{T}$ cells (Figure S2). Moreover, $\mathrm{T}\left(\mathrm{DC}^{\mathrm{IL}-10}\right)$ cells suppressed the proliferation of autologous $\mathrm{CD} 4^{+} \mathrm{T}$ cells stimulated with $\mathrm{mDC}$ from the same donor used for priming, with an average of $67 \%$ of suppression (Figure 4E). Overall, these findings indicate that bdLV-mediated IL-10 gene transfer in DC induces a cell population endowed with the ability to modulate allogeneic $\mathrm{T}$ cell responses and promote the differentiation of alloantigen-specific Tr1 cells in vitro.

\section{Human DC'L-10 Are Phenotypically and Functionally Stable Cells}

One of the major hurdles in the use of tolDC as cell product is their stability, thus we investigated the impact of 

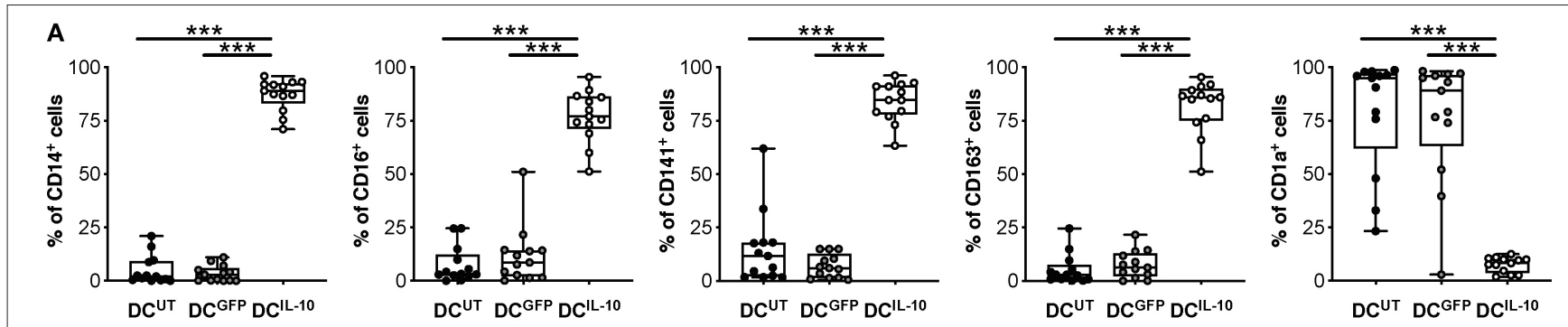

B

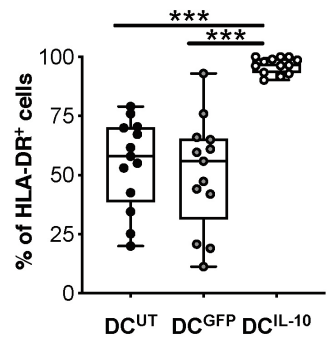

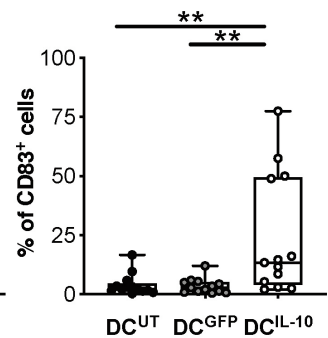
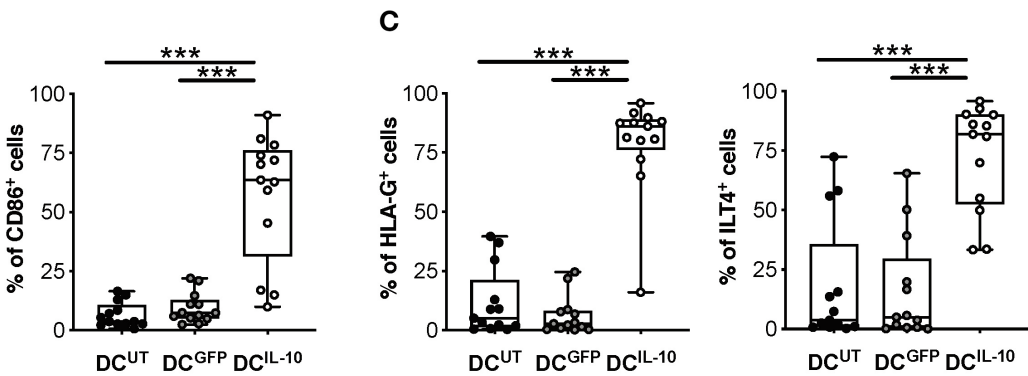

FIGURE 2 | DC $C^{\mathrm{LL}-10}$ are myeloid mature cells and express markers associated with tolerogenic DC-10. DC ${ }^{\mathrm{LL}-10}$ were differentiated as described in method section. At the end of differentiation, the expression of the indicated markers was evaluated by flow cytometry. (A) Markers associated with DC-10 differentiation (CD14, CD16, CD163, CD141 CD1a); (B) HLA class II (HLA-DR), and co-stimulatory (CD83 and CD86) molecules; (C) Tolerogenic molecules (HLA-G and ILT4). Each dot represents a single donor $(n=13)$, lines indicate median, while whiskers are minimum and maximum levels. ${ }^{\star \star} P \leq 0.01,{ }^{\star \star \star} P \leq 0.001$ (Wilcoxon matched pairs test, two-tailed).
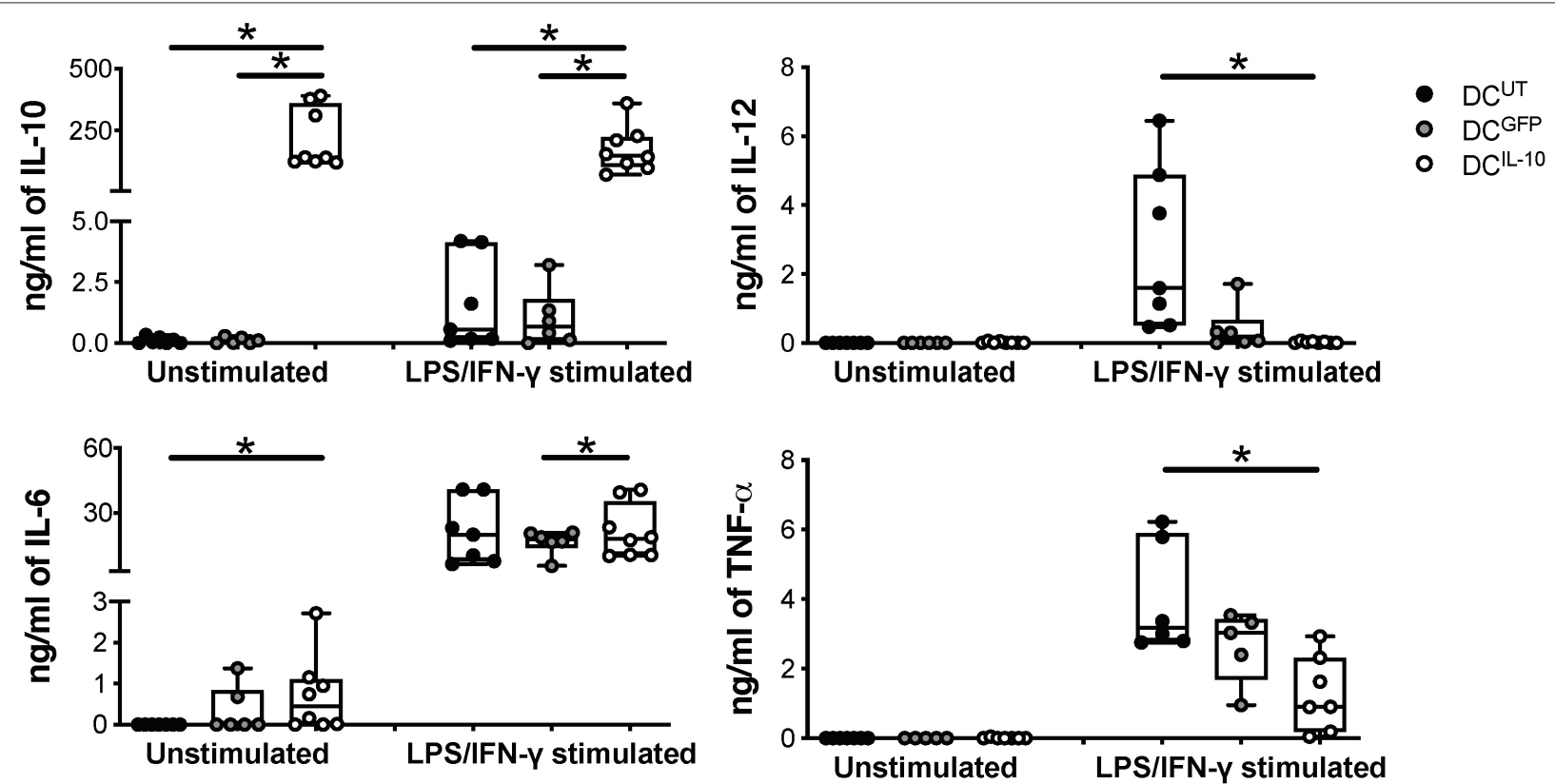

FIGURE 3 | DC $\mathrm{DC}^{\mathrm{IL}-10}$ secrete supra-physiological levels of IL-10 and low levels of pro-inflammatory cytokines at steady state and upon activation. At the end of differentiation, $2 \times 10^{5}$ DC were plated in $200 \mu$ l and left unstimulated or stimulated with LPS and IFN- $\gamma$ for $48 \mathrm{~h}$. Concentration levels of IL-10, IL-12, IL-6, and TNF- $\alpha$ in culture supernatants were evaluated by ELISA. Each dot represents a single donor $(n=6-8)$, lines indicate median, while whiskers are minimum and maximum levels. ${ }^{*} P \leq 0.05$ (Wilcoxon matched pairs test, two-tailed).

a pro-inflammatory milieu on the phenotype and functions of $\mathrm{DC}^{\mathrm{IL}-10}$. To this end, we assessed phenotype and function of $\mathrm{DC}^{\mathrm{IL}-10}$ stimulated in vitro with different toll-like receptor
(TLR) agonists (LPS, Listeria, Flagellin, Poli I:C, and CpG) or with a mix of pro-inflammatory cytokines (IL-1 $\beta$, TNF$\alpha$, and IL-6). No major changes in $\mathrm{DC}^{\mathrm{IL}-10}$ phenotype were 


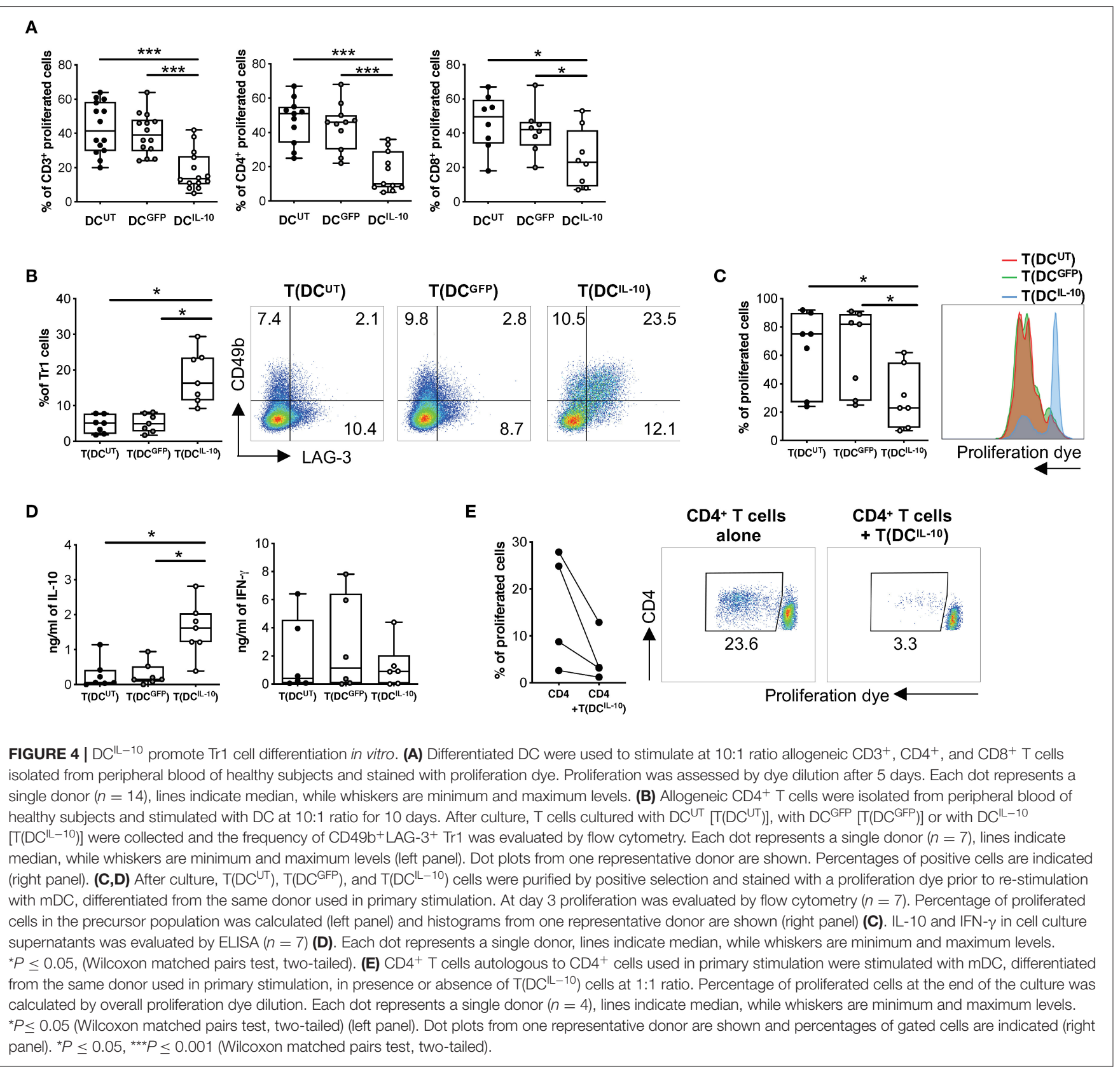

observed upon activation, with the exception of a significant down-regulation of CD16 upon Listeria and CpG stimulation, and a significant upregulation of CD86 upon Listeria- and LPS-mediated activation (Figures 5A,B). In line with results obtained in DC-10 (33), DC ${ }^{\mathrm{IL}-10}$ stably expressed CD141, and CD163 independently from the stimuli used (Figure 5A). Furthermore, DC ${ }^{\mathrm{IL}-10}$ maintained their ability to secrete high amounts of IL-10 in the absence of IL-12, independently from the stimulation used. Activation with LPS, Listeria, and Flagellin of DC $\mathrm{CL}^{\mathrm{IL}-10}$ promoted significantly higher levels of IL- 6 and TNF- $\alpha$ compared to unstimulated conditions (Figure S3). Thus,
$\mathrm{DC}^{\mathrm{IL}-10}$ are phenotypically stable cells and activation with some TLR agonists further promote their activation, as demonstrated by the up-regulation of CD86 and the increase in IL- 6 and TNF- $\alpha$ secretion.

Analysis of the expression of the tolerogenic molecules HLA-G and ILT4 on DC ${ }^{\mathrm{IL}-10}$ showed that, among the different stimuli used, TLR3- and TLR4-mediated activation had opposite effects: Poli I:C exposure increased HLA-G and decreased ILT4, while LPS stimulation down-regulated HLA-G and up-regulated ILT4 (Figure 6A, Figure S4). Since HLA-G and ILT4 are involved in DC-10-mediated induction 
A
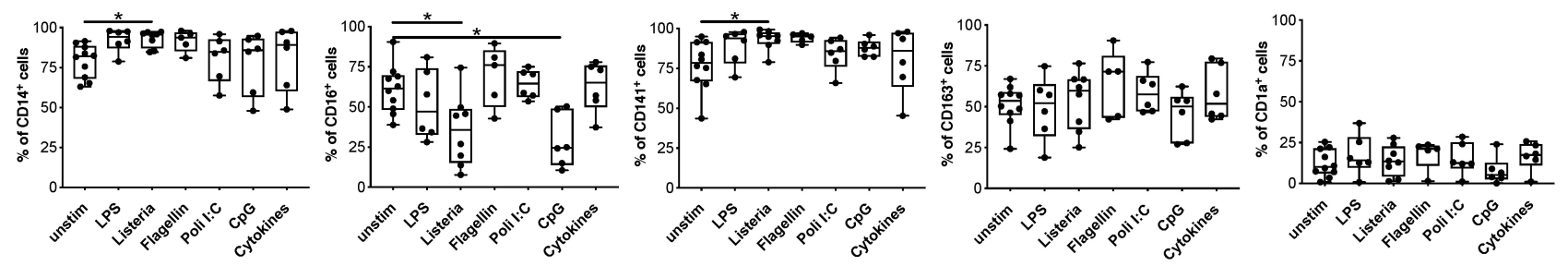

B

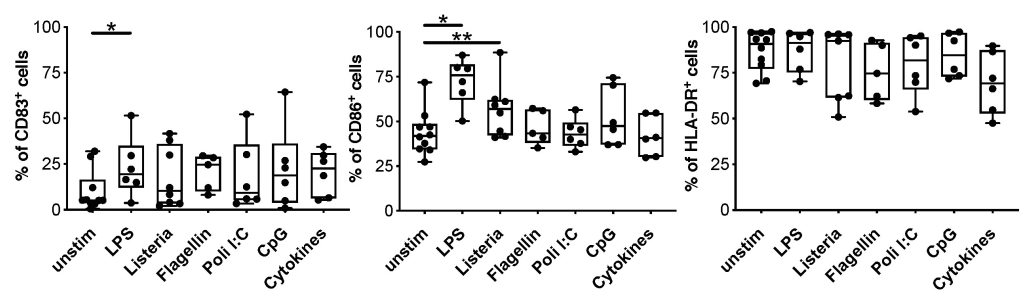

FIGURE 5 | Upon activation, DC ${ }^{\mathrm{LL}-10}$ maintain their phenotype. At the end of differentiation, DC ${ }^{\mathrm{LL}-10}$ were activated with LPS, Heat Killed Listeria Monocytogenes, Flagellin S. typhimurium, Poli I:C, ODN2006 (CpG), or a mix of cytokines (IL-1 $\beta$, TNF- $\alpha$, and IL-6). After $24 \mathrm{~h}$, the expression of the indicated markers was evaluated by flow cytometry. (A) Markers associated with DC-10 differentiation (CD14, CD16, CD163, CD141 CD1a); (B) HLA class II (HLA-DR), and co-stimulatory (CD83 and CD86) molecules $(n=5-10)$. Each dot represents a single donor, lines indicate median, while whiskers are minimum and maximum levels. ${ }^{\star} P \leq 0.05$, ${ }^{\star *} P \leq 0.01$ (Wilcoxon matched pairs test, two-tailed).

of $\operatorname{Tr} 1$ cells (32), we investigated how $\mathrm{DC}^{\mathrm{IL}-10}$ tolerogenic activity varied upon stimulation with LPS (DC $\mathrm{DL}^{\mathrm{IL}-10-\mathrm{LPS}}$ ) and Poli $\mathrm{I}: \mathrm{C}\left(\mathrm{DC}^{\mathrm{IL}-10-\mathrm{POLI}}\right)$. In line with the changes in HLA-G levels, the percentage of $\operatorname{Tr} 1$ cells induced at the end of $\mathrm{T}$ cell differentiation was higher in $\mathrm{T}$ cells induced by $\mathrm{DC}^{\mathrm{IL}-10-\mathrm{POLI}}$ and lower in $\mathrm{T}$ cells induced by $\mathrm{DC}^{\mathrm{IL}-10-\mathrm{LPS}}$. Despite these differences, all the three $\mathrm{DC}^{\mathrm{IL}-10}$ populations induced $\mathrm{Tr} 1$ cells at a higher efficiency when compared to control DC ${ }^{\mathrm{GFP}}$ (Figure 6B). No major differences in proliferative capacity, cytokine profile and suppressive ability were observed among $\operatorname{Tr} 1$ cells generated with unstimulated $\mathrm{DC}^{\mathrm{IL}-10}, \mathrm{DC}^{\mathrm{IL}-10-\mathrm{LPS}}$, and $\mathrm{DC}^{\mathrm{IL}-10-\mathrm{POLI}}$, showing that $\mathrm{DC}^{\mathrm{IL}-10}$ maintained their tolerogenic activity upon pro-inflammatory stimulation (Figures 6C,D). Overall, these data indicate that activated $\mathrm{DC}^{\mathrm{IL}-10}$ are as powerful as their steady state counterpart in modulating $\mathrm{T}$ cell responses and in promoting $\operatorname{Tr} 1$ cells in vitro, suggesting that activation does not impair the modulatory activity and tolerogenic potential of $\mathrm{DC}^{\mathrm{IL}-10}$.

\section{Human DC ${ }^{\mathrm{IL}-10}$ Modulate Allogeneic T cell Responses in vivo}

To assess the modulatory activity of $\mathrm{DC}^{\mathrm{IL}-10}$ in vivo we took advantage of the recently developed protocol for the repopulation of NSG mice with human cord blood $\mathrm{CD}_{3}{ }^{+}$cells. Intra-liver injection of human $\mathrm{CD}^{+}{ }^{+}$cells in sub-lethally irradiated neonate NSG mice allowed efficient engraftment of human $\mathrm{CD} 45^{+}$hematopoietic cells in bone marrow (BM) and differentiation of lymphoid ( $\mathrm{B}$ and $\mathrm{T}$ effector, and $\mathrm{T}$ regulatory) and myeloid cells in the periphery (28). We immunized reconstituted huMice by injection of irradiated allogeneic human $\mathrm{CD}^{-}$cells, which act as antigen presenting cells, and provided, after seven days, a second challenge by injecting autologous $\mathrm{DC}^{\mathrm{UT}}$. To assess the modulatory activity of $\mathrm{DC}^{\mathrm{IL} 10}$, we co-injected $\mathrm{DC}^{\mathrm{IL}-10}$ $\left(\mathrm{DC}^{\mathrm{UT}}+\mathrm{DC}^{\mathrm{IL} 10}\right)$ or, as control, $\mathrm{DC}^{\mathrm{GFP}}\left(\mathrm{DC}^{\mathrm{UT}}+\mathrm{DC}^{\mathrm{GFP}}\right)$ (Figure 7A). While treatment with $\mathrm{DC}^{\mathrm{GFP}}$ induced a boost in $\mathrm{CD}^{+} \mathrm{T}$ cell proliferation in vivo, as assessed by $\mathrm{Ki67}$ staining of peripheral blood lymphocytes 3 days after the re-challenge, $\mathrm{DC}^{\mathrm{IL}-10}$ dampened the response induced by allogeneic DC ${ }^{\mathrm{UT}}$. In all the three conditions, the immune system returned at steady state after 5 days from the rechallenge, with comparable proliferation levels observed in all mice (Figure 7B).

\section{Intravenously Injected Murine DC ${ }^{\mathrm{IL}-10}$ Engraft Lung and Bone Marrow and Delay Acute Graft-vs. Host Disease}

We next investigated the potential therapeutic effect of $\mathrm{DC}^{\mathrm{IL}-10}$ in a pre-clinical model of acute graft-vs. host disease (GvHD). To do so, we generated and characterized the murine counterpart of the human $\mathrm{DC}^{\mathrm{IL}-10}$. We transduced Balb/c $(\mathrm{H}-$ 2d) BM cells with LV-IL-10 and LV-GFP at day 2 during DC differentiation and activated them with LPS in the last 2 days of culture. Murine DC were efficiently transduced with LV-IL-10 and LV-GFP, as demonstrated by an average 67.3 and $67.1 \%$ of $\triangle \mathrm{NGFR}^{+}$cells, respectively (Figure 8A). In contrast to $\mathrm{DC}^{\mathrm{GFP}}, \mathrm{DC}^{\mathrm{IL}-10}$ showed lower expression levels of CD83, while the expression of MHC class II, CD80, and CD86 was comparable (Figure 8A). As expected, DC $\mathrm{DC}^{\mathrm{IL}-10}$ showed human IL-10 expression at steady state and upon 


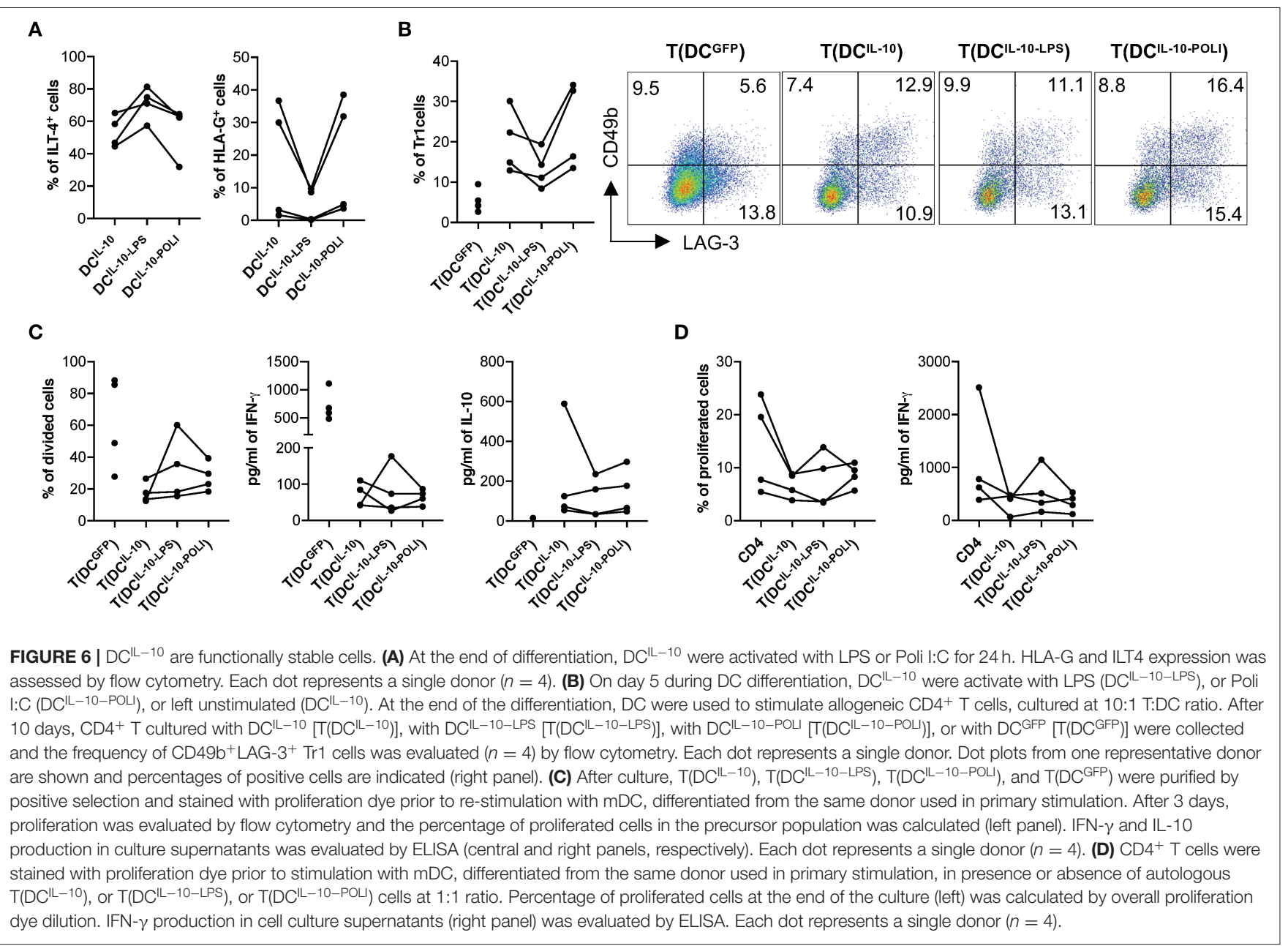

activation, which was not detected in $\mathrm{DC}^{\mathrm{GFP}}$ Similar to human $\mathrm{DC}^{\mathrm{IL}-10}$, murine $\mathrm{DC}^{\mathrm{IL}-10}$

(Figure 8B). promoted a significantly lower proliferative allogeneic $\mathrm{T}$ cell response compared to that elicited by $\mathrm{DC}^{\mathrm{GFP}}$, both in $\mathrm{CD}^{+}$and $\mathrm{CD} 8^{+}$ T cells (Figure 8C).

To study murine $\mathrm{DC}^{\mathrm{IL}-10}$ biodistribution, we transduced BM cells during DC differentiation with a bdLV encoding for luciferase and IL-10 ( $\left.\mathrm{DC}^{\mathrm{IL}-10}\right)$ or $\triangle \mathrm{NGFR}\left(\mathrm{DC}^{\mathrm{NGFR}}\right)$. $\mathrm{DC}^{\mathrm{IL}-10}$ and control DC ${ }^{\mathrm{NGFR}}$ were then intravenously injected alone or in combination with autologous BM cells in lethally irradiated female Balb/c mice. The difference in the 1st day signals between $\mathrm{DC}^{\mathrm{IL}-10}$ - and $\mathrm{DC}^{\mathrm{NGFR}}$-injected mice was very likely due to a higher transduction of $\mathrm{DC}^{\mathrm{IL}-10}$ (Figure 9A). In all groups we observed a consistent decrease in total flux in the first 2 days after DC injection, and both cell types localized in the lung (Figure 9B). Between day 2 and 5 lung signal dropped, and increased signal was registered in the legs of all mice (Figure 9C). When BM cells were coinjected, a different behavior was observed between $\mathrm{DC}^{\mathrm{IL}-10}$ and $\mathrm{DC}^{\mathrm{NGFR}}$. $\mathrm{DC}^{\mathrm{NGFR}}$ migrated to the legs with the same kinetic irrespectively of the presence or absence of BM cells, at least until day 6. Conversely, migration of $\mathrm{DC}^{\mathrm{IL}-10}$ to the bones is limited by the presence of BM cells, while when mice are not replenished with BM cells it is increased, even at higher rate compared to $\mathrm{DC}^{\mathrm{NGFR}}$, probably due to an enhanced recruitment induced by the aplastic/hypoplastic bone marrow upon irradiation.

Finally, we evaluated the potential therapeutic effect of $\mathrm{DC}^{\mathrm{IL}-10}$ in GvHD. Lethally irradiated female $\mathrm{Balb} / \mathrm{c}$ recipients were transplanted with $\mathrm{BM}$ cells and splenocytes isolated from female $\mathrm{C} 57 \mathrm{Bl} / 6$ mice, and 2 days after transplantation mice received $\mathrm{Balb} / \mathrm{c}$-derived $\mathrm{DC}^{\mathrm{IL}-10}$ or $\mathrm{DC}^{\mathrm{GFP}}$, or were left untreated as control (Figure 10A). This experimental setting induced a strong GvHD, since all mice of the control group died within 24 days (Figure 10B). Administration of Balb/c $\mathrm{DC}^{\mathrm{IL}-10}$ improved the survival time of mice compared to both control groups (50\% survival at day 24 ), while Balb/c DC GFP treatment enhanced GvHD lethality (Figure 10B). Interestingly, treatment with $\mathrm{DC}^{\mathrm{IL}-10}$ clearly modulated not only the survival but also the severity of GvHD phenotype in mice, compare to 


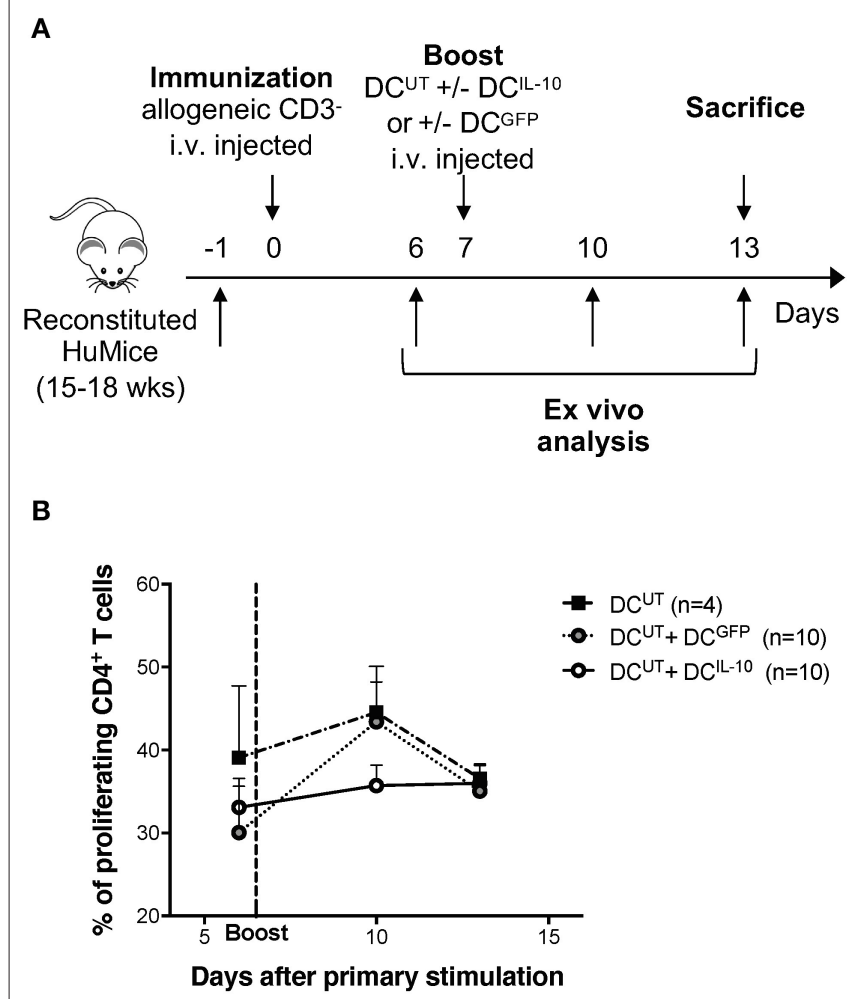

FIGURE 7 | DC $C^{\mathrm{LL}-10}$ prevent allo-specific T cell reactivation in huMice. NSG mice were transplanted with $10^{5} \mathrm{CD} 34^{+}$human cells. Reconstituted huMice were immunized with i.v. injected irradiated allogeneic $\mathrm{CD}^{-}$cells $(n=24)$. On day 7 , immunized huMice were boosted with autologous un-transduced DC $\left(\mathrm{DC}^{\mathrm{UT}}\right)$ alone $(n=4)$, or in combination with $\mathrm{DC}^{\mathrm{LL}-10}\left(\mathrm{DC}^{\mathrm{UT}}+\mathrm{DC}^{\mathrm{IL} 10}\right)(n=10)$, or DC ${ }^{G F P}$ (DC UT +DC GFP) $(n=10)$. (A) Experimental design is depicted. (B) Peripheral blood CD4 ${ }^{+} \mathrm{T}$ cell proliferation was assessed by Ki67 staining at day 6, 10, and 13 from immunization. Mean values and SEM are shown.

both untreated and DC ${ }^{\mathrm{GFP}}$-treated mice groups, as shown by weight loss and score assessment at day 24 (Figure 10C). These results support the potential clinical application of $\mathrm{DC}^{\mathrm{IL}-10}$ as cell-based approach to control $\mathrm{T}$ cell responses in allogeneic transplantation setting.

\section{DISCUSSION}

We designed a powerful method to genetically engineer monocyte-derived DC using bdLV to over-express IL-10 in combination with a marker gene, allowing in vitro selection, and in vivo tracking of $\mathrm{DC}^{\mathrm{IL}-10}$. $\mathrm{DC}^{\mathrm{IL}-10}$ display a strong tolerogenic profile since they: secrete supra-physiological levels of IL-10 at steady state and upon activation, but no proinflammatory IL-12; modulate $\mathrm{CD}^{+}{ }^{+}$and $\mathrm{CD} 8^{+} \mathrm{T}$ cell responses and differentiate alloantigen-specific $\operatorname{Tr} 1$ cells in vitro; and are phenotypically and functionally stable upon TLR-mediated or cytokine-mediated activation. More importantly, human $\mathrm{DC}^{\mathrm{IL}-10}$ modulate allogeneic $\mathrm{CD}^{+} \mathrm{T}$ cell responses in vivo in immunized humanized mice and preliminary data showed that murine $\mathrm{DC}^{\mathrm{IL}-10}$, which share phenotypic and functional
A
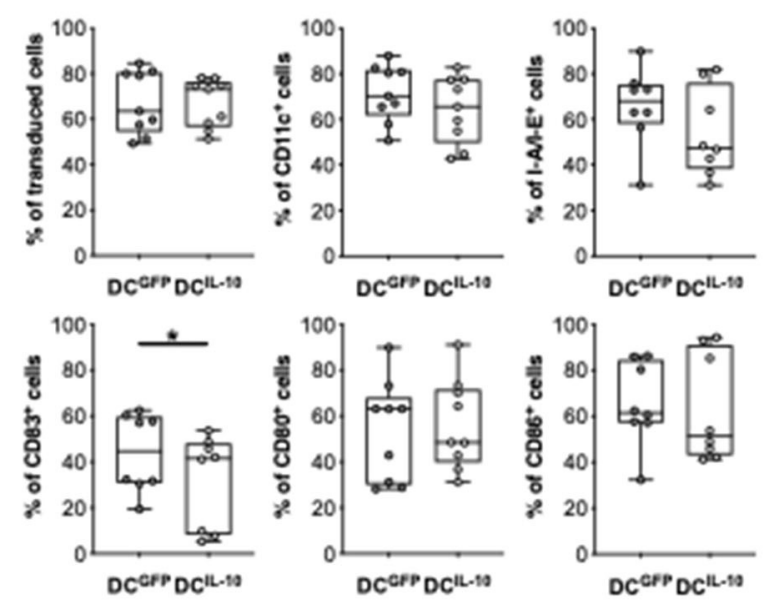

B

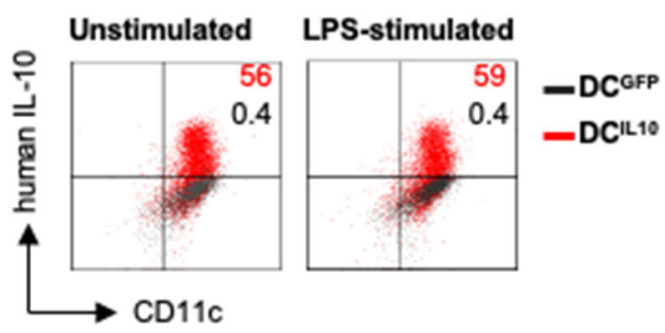

C

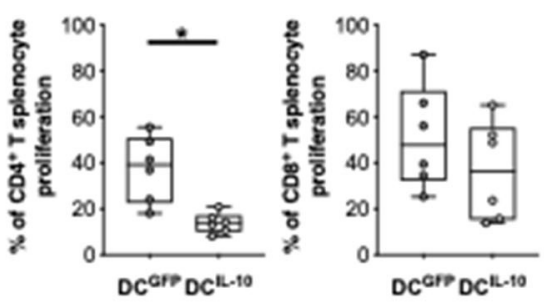

FIGURE 8 | In vitro characterization of murine DC ${ }^{\mathrm{L}-10}$. Female Balb/c BM cells were differentiated into DC, transduced at day 2 with LV-GFP (DCGFP) or LV-IL-10 (DC $\left.{ }^{\mathrm{L}-10}\right)$, and activated with LPS $(200 \mathrm{ng} / \mathrm{ml})$ during the last 2 days of differentiation. (A) Transduction efficiency was quantified based on $\triangle$ NGFR expression and the expression of the indicated markers was analyzed at day 9 of differentiation by flow cytometry. Each dot represents a single experiment $(n=8-9)$, lines indicate median, while whiskers are minimum and maximum levels. (B) DC were plated and left unstimulated or stimulated with LPS ( $200 \mathrm{ng} / \mathrm{ml}$ ) for $24 \mathrm{~h}$, with the addition of brefeldin A at $6 \mathrm{~h}$. The expression of human IL-10 was quantified by intracytoplasmic staining. One representative donor out of two is depicted, and percentages of positive cells are indicated. (C) Spleen cells from female C57BI/6 mice were stained with a proliferation dye and stimulated with Balb/c DCGFP and DC $\mathrm{CL}^{\mathrm{LL}-10}$ at 1:10 ratio. At day 5, proliferation of $\mathrm{CD}^{+}$and $\mathrm{CD} 8^{+} \mathrm{T}$ cells was measured by flow cytometry. Each dot represents a single donor $(n=6)$, lines indicate median, while whiskers are minimum and maximum levels. ${ }^{*} P \leq 0.05$ (Wilcoxon matched pairs test, two-tailed).

characteristics with human $\mathrm{DC}^{\mathrm{IL}-10}$, delay mice mortality in a model of acute GvHD, dampening the clinical signs of the pathology. 
A

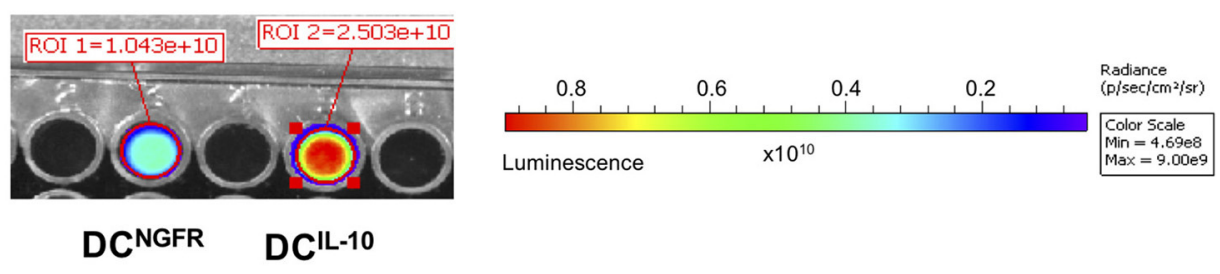

B

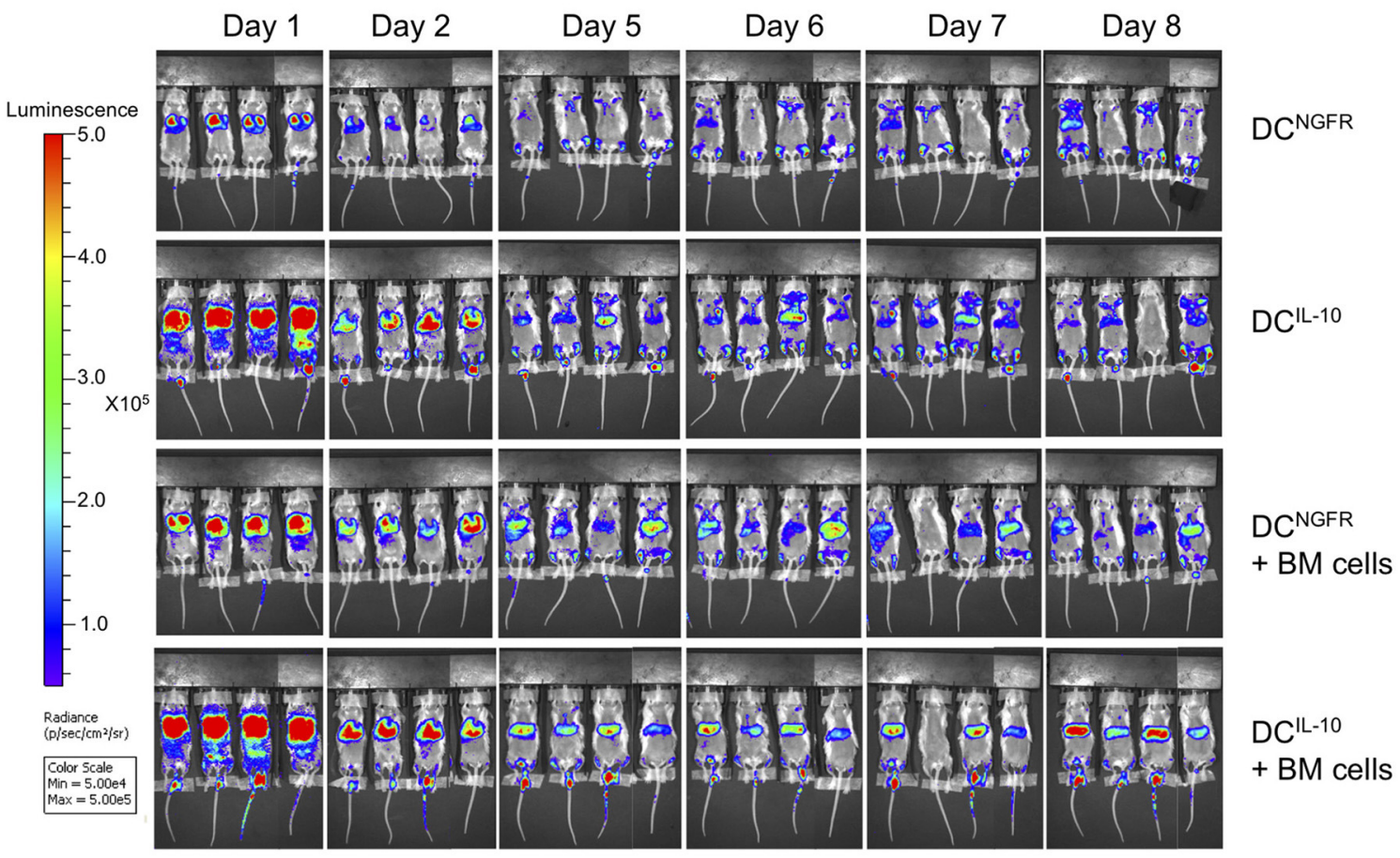

C

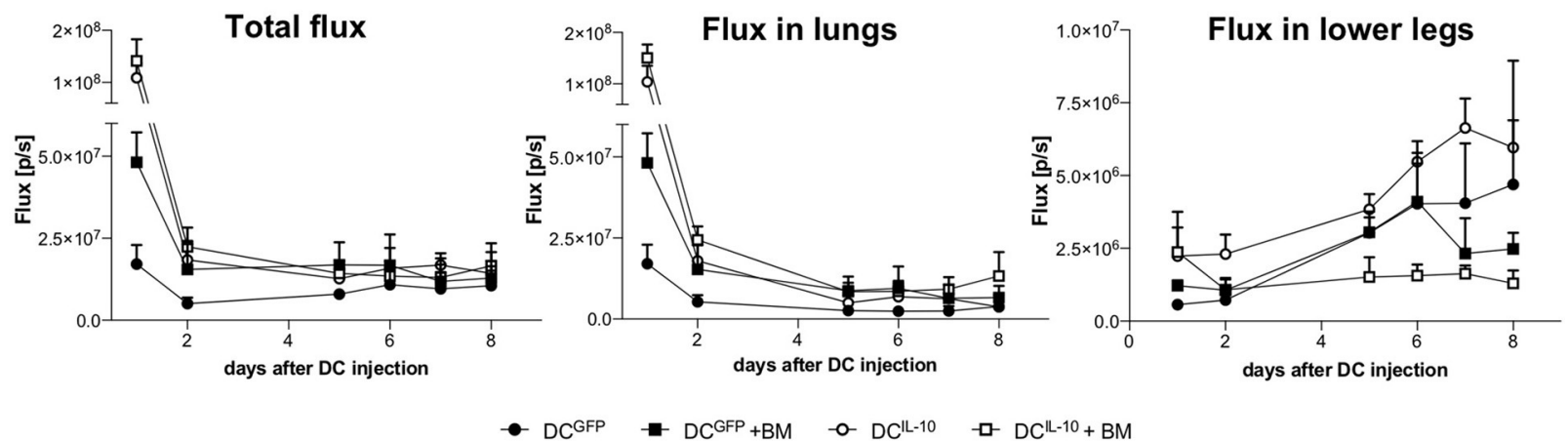

FIGURE 9 | Biodistribution of transduced DC. Female Balb/c BM cells were transduced at day 2 during DC differentiation with bdLV encoding for luciferase and IL-10 $\left(\mathrm{DC}^{\mathrm{L}-10}\right.$ ) or $\triangle$ NGFR (DC NGFR). (A) Transduction efficiency was evaluated adding luciferin to a well with $2 \times 10^{5} \mathrm{DCs}$ and reading the bioluminescent signal. (B,C) Female Balb/c mice were lethally irradiated and intravenously injected with luciferase-transduced DC ${ }^{\mathrm{NGFR}}$ or DC $\mathrm{CL}^{\mathrm{L}-10}\left(2 \times 10^{6} \mathrm{cells} / \mathrm{mouse}\right)$ alone or in combination with autologous BM cells ( $10^{7}$ cells/mouse) ( $n=4$ mice for group). DC localization was monitored with bioluminescence imaging (BLI) at the indicated time points. Single mice scanning (B) and quantification of BLI at the indicated time points (C) are shown.

We applied, for the first time, the genetic modification of human monocyte-derived DC with bdLV-encoding for IL10 and $\triangle$ NGFR, to obtain IL-10 over-expressing tolDC. IL10 transduction has been exploited to generate murine bone marrow-derived IL-10-producing tolDC (34), and used to promote antigen-specific tolerance in vivo via Treg induction (35, 36 ), or to differentiate IL-10-producing Tr1 cells in vitro suitable for cell-based approaches in preclinical models of GvHD (37). 


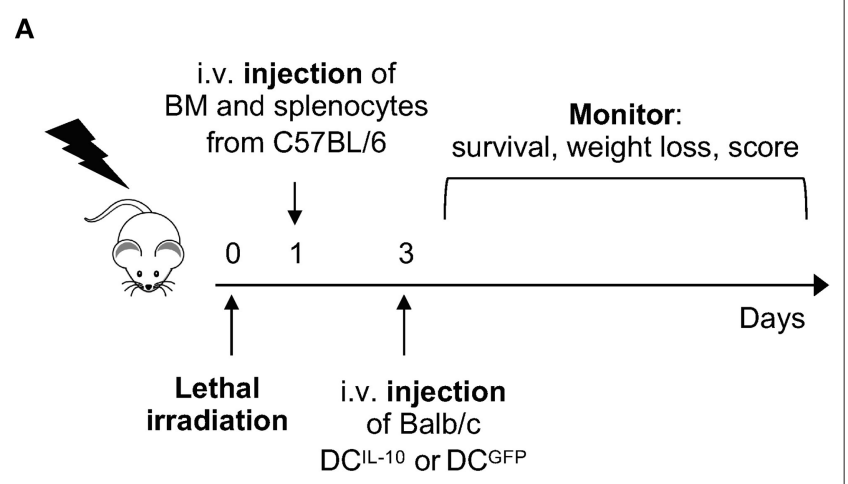

B

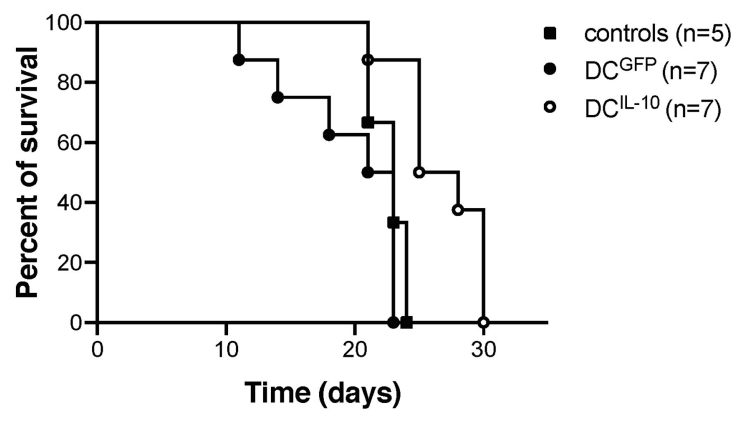

C

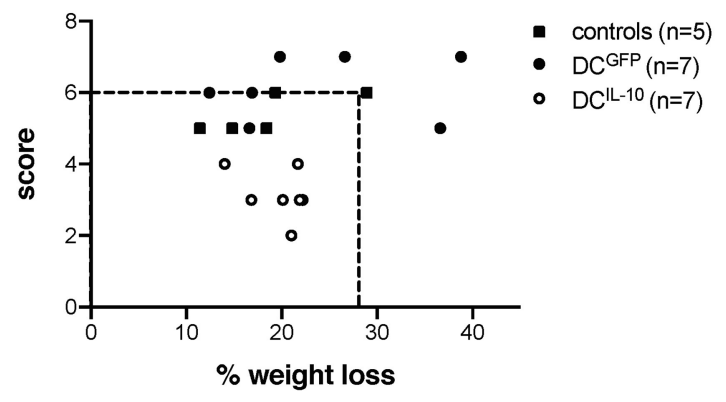

FIGURE 10 | Adoptive transfer of DC ${ }^{\mathrm{L}-10}$ delays acute graft-vs. host disease. Female Balb/c mice were lethally irradiated and then intravenously injected with $10^{7} \mathrm{BM}$ cells and $5 \times 10^{6}$ splenocytes from female C57BI/ 6 mice the day after. On day 3 , mice were left untreated $(n=5)$ or were adoptively transferred with $2 \times 10^{6} \mathrm{DC}^{\mathrm{GFP}}(n=7)$, or $2 \times 10^{6} \mathrm{DC}^{\mathrm{IL}-10}(n=7)$. Survival, weight loss and score of mice was monitored every other day. (A) Experimental design is depicted. (B) Survival of mice was observed over time. One representative experiment out of three is shown. (C) The score (fur, hunch, skin lesion, mobility) and the weight loss of mice at day 25 is represented, dashed lines represent the criteria for euthanasia (score $>6$ or $>25 \%$ of weight loss). One representative experiment out of three is shown.

Human DC ${ }^{\mathrm{IL}-10}$ differ from IL-10-treated human monocytederived immature and mature DC that express reduced levels of HLA-DR and costimulatory molecules, leading to decreased ability to activate allogeneic $\mathrm{T}$ cells (38-40). Indeed, human DC $^{\mathrm{IL}-10}$ express HLA-DR, CD83 and CD86 molecules at higher levels compared to control DC, but despite their mature phenotype, they induce suppressive allogeneic $\mathrm{T}$ cells in vitro and modulate allogeneic $\mathrm{T}$ cell responses in vivo. $\mathrm{DC}^{\mathrm{IL}-10}$ are phenotypically and functionally super-imposable to DC-10, which, although differentiated in the presence of IL-10, express HLA-DR and costimulatory molecules at higher levels compared to control DC (32), and are stable upon TLR-activation (33).

Like for DC-10, the ability of $\mathrm{DC}^{\mathrm{IL}-10}$ to induce $\operatorname{Tr} 1$ cells in vitro relies not only on the IL-10 secretion, but also on the expression of the tolerogenic molecules HLA-G and ILT4 (32, 41). Their expression is modulated by TLR-mediated stimulation, but with opposite effects: bacterial derived antigens (e.g., LPS and Listeria), decrease HLA-G and up-regulate ILT4, while viral stimuli, such as Poli I:C and CpG, increase HLA-G and downregulate ILT4. These variations influence the proportion of $\operatorname{Tr} 1$ cells induced by $\mathrm{DC}^{\mathrm{IL}-10}$, but they do not affect the anergic and suppressive phenotype of the generated $\operatorname{Tr} 1$ cells, indicating that the high levels of IL-10 secreted by activated $\mathrm{DC}^{\mathrm{IL}-10}$ compensate for the alteration in the signaling mediated by HLA$\mathrm{G}$ or ILT4. This conclusion is in line with data obtained with tolDC generated in the presence of G-CSF (G-DC), that although express ILT4 and HLA-G at levels comparable to DC-10, do not promote the differentiation of suppressive Tr1 cells (42), because G-DC produce significantly lower levels of IL-10 compared to DC-10 (32).

The ability of tolDC to generate long-term tolerance to the transplant has been proposed as an alternative to current pharmacological approaches used to avoid graft rejection or to prevent GvHD based on general immunosuppression, which could lead to an impairment of the immune system, increasing the risk of infection and cancer (43-46). One of the problems, in the application of tolDC as cell therapy is the stability of the product and the maintenance of their tolerogenic properties in vivo. Here, we showed that in vitro activation does not strongly affect significantly $\mathrm{DC}^{\mathrm{IL}-10}$ phenotype or cytokine profile and, despite alteration of the tolerogenic molecule HLA-G and ILT4, their ability to induce $\operatorname{Tr} 1$ cells. More interestingly, despite $\mathrm{DC}^{\mathrm{IL}-10}$ administered in the GvHD model were activated with LPS, they exert their modulatory functions, prolonging the survival of treated mice, and dampening the clinical signs of GvHD in the experiments showed. Systemic administration of tolDC generated with different pharmacological manipulations has been previously shown to modulate GvHD in murine models (47-49). However, different schedule of tolD administration and doses were tested, making comparison difficult. Nevertheless, we cannot exclude that multiple $\mathrm{DC}^{\mathrm{IL}-10}$ administration, as demonstrated with tolDC manipulated with HDAC inhibitors (49), might results in further improvement of mice survival.

Further preclinical studies are warranted to optimize the protocol for $\mathrm{DC}^{\mathrm{IL}-10}$ administration, but preliminary data presented here suggest $\mathrm{DC}^{\mathrm{IL}-10}$ represent a promising cell product for clinical applications: they are stable cells with suppressive functions and as dendritic cells, they have a limited life span in vivo, restraining the long-lasting impact on immunity against infections and malignancies. $\mathrm{DC}^{\mathrm{IL}-10}$ induce allo-specific hypo-responsiveness in effector $\mathrm{CD}^{+}$and $\mathrm{CD}^{+} \mathrm{T}$ cells and, through the stable over-expression of IL-10, we hypothesize they generate a local microenvironment enriched in IL-10 that 
modulate not only $\mathrm{T}$ cells, but also myeloid and innate cells, thus sustaining long-term tolerance.

\section{DATA AVAILABILITY STATEMENT}

The raw data supporting the conclusions of this article will be made available by the authors, without undue reservation.

\section{ETHICS STATEMENT}

The animal study was reviewed and approved by the OSR Institutional Animal Care and Use Committee (IACUC protocol \#488, \#632, and \#748), following the 3R principles (replacement, reduction, and refinement), and the Decreto Legislativo \#116 dated January 27th, 1992, from the Italian Parliament.

\section{AUTHOR CONTRIBUTIONS}

MC performed the experiments, collected, analyzed, and interpreted data, performed statistical analysis, and wrote the manuscript. LP, MF, GAm, and GAn performed some of the experiments. FS conceived, performed, and analyzed humanized

\section{REFERENCES}

1. Moreau A, Alliot-Licht B, Cuturi M-C, Blancho G. Tolerogenic dendritic cell therapy in organ transplantation. Transpl Int. (2017) 30:754-64. doi: 10.1111/tri.12889

2. Waisman A, Lukas D, Clausen BE, Yogev N. Dendritic cells as gatekeepers of tolerance. Semin Immunopathol. (2017) 39:15363. doi: 10.1007/s00281-016-0583-Z

3. Rastellini C, Lu L, Ricordi C, Starzl TE, Rao AS, Thomson AW. Granulocyte/macrophage colony-stimulating factor-stimulated hepatic dendritic cell progenitors prolong pancreatic islet allograft survival. Transplantation. (1995) 60:1366-70.

4. Fu F, Thai NL, Li Y, Lu L, Thomson AW, Fung JJ, et al. Secondset rejection of mouse liver allografts is dependent on radiation-sensitive nonparenchymal cells of graft bone marrow origin. Transplantation. (1996) 61:1228-33. doi: 10.1097/00007890-199604270-00019

5. Zhou Y, Shan J, Guo Y, Li S, Long D, Li Y, et al. Effects of adoptive transfer of tolerogenic dendritic cells on allograft survival in organ transplantation models: an overview of systematic reviews. J Immunol Res. (2016) 2016:5730674. doi: 10.1155/2016/5730674

6. Ochando J, Ordikhani F, Jordan S, Boros P, Thomson AW. Tolerogenic dendritic cells in organ transplantation. Transpl Int. (2020) 33:113127. doi: $10.1111 /$ tri.13504

7. Amodio G, Cichy J, Conde P, Matteoli G, Moreau A, Ochando J, et al. Role of myeloid regulatory cells (MRCs) in maintaining tissue homeostasis and promoting tolerance in autoimmunity, inflammatory disease and transplantation. Cancer Immunol Immunother. (2019) 68:66172. doi: 10.1007/s00262-018-2264-3

8. Hutchinson JA, Riquelme P, Sawitzki B, Tomiuk S, Miqueu P, Zuhayra $\mathrm{M}$, et al. Cutting edge: Immunological consequences and trafficking of human regulatory macrophages administered to renal transplant recipients. J Immunol. (2011) 187:2072-8. doi: 10.4049/jimmunol.1100762

9. Benham H, Nel HJ, Law SC, Mehdi AM, Street S, Ramnoruth N, et al. Citrullinated peptide dendritic cell immunotherapy in HLA risk genotype-positive rheumatoid arthritis patients. Sci Transl Med. (2015) 7:290ra87. doi: 10.1126/scitranslmed.aaa9301

10. Bell GM, Anderson AE, Diboll J, Reece R, Eltherington O, Harry RA, et al. Autologous tolerogenic dendritic cells for rheumatoid and mice experiments. LP, FR, LC, and GAn performed the in vivo experiments. LC produced lentiviral vectors. AK-R contributed Vpx plasmid reagent. SG conceived the scientific idea, supervised the project, intertreted data and wrote the manuscript.

\section{FUNDING}

This work was supported by research funding from the Italian Telethon Foundation (TGT18-19G01) and the Italian Association for Cancer Research, IG-18540, AIRC 2016 to SG.

\section{ACKNOWLEDGMENTS}

We thank Dr. Antonello Spinelli for bioluminescence assay data acquisition and analysis, Dr. Laura Passerini for the help with data analysis and Dr. Francesco Piras for the help with Vpxplasmid reagent.

\section{SUPPLEMENTARY MATERIAL}

The Supplementary Material for this article can be found online at: https://www.frontiersin.org/articles/10.3389/fimmu. 2020.01260/full\#supplementary-material inflammatory arthritis. Ann Rheum Dis. (2016) 73. doi: 10.1136/ annrheumdis-2015-208456

11. Giannoukakis N, Phillips B, Finegold D, Harnaha J, Trucco M. Phase I (safety) study of autologous tolerogenic dendritic cells in type 1 diabetic patients. Diabetes Care. (2011) 34:2026-32. doi: 10.2337/dc11-0472

12. Willekens B, Presas-Rodríguez S, Mansilla MJ, Derdelinckx J, Lee W $\mathrm{P}$, Nijs G, et al. Tolerogenic dendritic cell-based treatment for multiple sclerosis (MS): a harmonised study protocol for two phase I clinical trials comparing intradermal and intranodal cell administration. BMJ Open. (2019) 9:e030309. doi: 10.1136/bmjopen-2019-030309

13. Jauregui-Amezaga A, Cabezón R, Ramírez-Morros A, España C, Rimola J, Bru $\mathrm{C}$, et al. Intraperitoneal administration of autologous tolerogenic dendritic cells for refractory crohn's disease: a phase I study. J Crohns Colitis. (2015) 9:1071-8. doi: 10.1093/ecco-jcc/jjv144

14. Gordon JR, Ma Y, Churchman L, Gordon SA, Dawicki W. Regulatory dendritic cells for immunotherapy in immunologic diseases. Front Immunol. (2014) 5:7. doi: 10.3389/fimmu.2014.00007

15. Horton C, Shanmugarajah K, Fairchild PJ. Harnessing the properties of dendritic cells in the pursuit of immunological tolerance. Biomed J. (2017) 40:80-93. doi: 10.1016/j.bj.2017.01.002

16. Navarro-Barriuso J, Mansilla MJ, Martínez-Cáceres EM. Searching for the transcriptomic signature of immune tolerance induction-biomarkers of safety and functionality for tolerogenic dendritic cells and regulatory macrophages. Front. Immunol. (2018) 9:2062. doi: 10.3389/fimmu.2018.02062

17. Comi M, Amodio G, Gregori S. Interleukin-10-Producing DC-10 is a unique tool to promote tolerance via antigen-specific t regulatory type 1 cells. Front Immunol. (2018) 9:682. doi: 10.3389/fimmu.2018.00682

18. Boks MA, Kager-Groenland JR, Haasjes MSP, Zwaginga JJ, van Ham SM, ten Brinke A. IL-10-generated tolerogenic dendritic cells are optimal for functional regulatory $\mathrm{T}$ cell induction-a comparative study of human clinical-applicable DC. Clin Immunol. (2012) 142:332-42. doi: 10.1016/ j.clim.2011.11.011

19. Hrecka K, Hao C, Gierszewska M, Swanson SK, Kesik-Brodacka M, Srivastava S, et al. Vpx relieves inhibition of HIV-1 infection of macrophages mediated by the SAMHD1 protein. Nature. (2011) 474:658-61. doi: 10.1038/ nature 10195

20. Laguette N, Sobhian B, Casartelli N, Ringeard M, Chable-Bessia C, Ségéral E, et al. SAMHD1 is the dendritic- and myeloid-cell-specific 
HIV-1 restriction factor counteracted by Vpx. Nature. (2011) 474:6547. doi: 10.1038 /nature10117

21. Lahouassa H, Daddacha W, Hofmann H, Ayinde D, Logue EC, Dragin L, et al. SAMHD1 restricts the replication of human immunodeficiency virus type 1 by depleting the intracellular pool of deoxynucleoside triphosphates. Nat Immunol. (2012) 13:223-28. doi: 10.1038/ni.2236

22. Kim B, Nguyen LA, Daddacha W, Hollenbaugh JA. Tight interplay among SAMHD1 protein level, cellular dNTP levels, and HIV-1 proviral DNA synthesis kinetics in human primary monocyte-derived macrophages. J Biol Chem. (2012) 287:21570-4. doi: 10.1074/jbc.C112.374843

23. Norton TD, Miller EA, Bhardwaj N, Landau NR. Vpx-containing dendritic cell vaccine induces CTLs and reactivates latent HIV-1 in vitro. Gene Ther. (2015) 22:227-36. doi: 10.1038/gt.2014.117

24. Norton TD, Zhen A, Tada T, Kim J, Kitchen S, Landau NR. Lentiviral vector-based dendritic cell vaccine suppresses HIV replication in humanized mice. Mol Ther. (2019) 27:960-73. doi: 10.1016/ j.ymthe.2019.03.008

25. Goujon C, Jarrosson-Wuillème L, Bernaud J, Rigal D, Darlix J-L, Cimarelli A. With a little help from a friend: increasing HIV transduction of monocytederived dendritic cells with virion-like particles of SIV(MAC). Gene Ther. (2006) 13:991-4. doi: 10.1038/sj.gt.3302753

26. Berger G, Durand S, Goujon C, Nguyen X-N, Cordeil S, Darlix J-L, et al. A simple, versatile and efficient method to genetically modify human monocytederived dendritic cells with HIV-1-derived lentiviral vectors. Nat Protoc. (2011) 6:806-16. doi: 10.1038/nprot.2011.327

27. De Palma M, Naldini L. Transduction of a gene expression cassette using advanced generation lentiviral vectors. Methods Enzymol. (2002) 346:51429. doi: 10.1016/S0076-6879(02)46074-0

28. Santoni de Sio FR, Passerini L, Restelli S, Valente MM, Pramov A, Maccari $\mathrm{ME}$, et al. Role of human forkhead box P3 in early thymic maturation and peripheral T-cell homeostasis. J Allergy Clin Immunol. (2018) 142:190921.e9. doi: 10.1016/j.jaci.2018.03.015

29. Gagliani N, Magnani CF, Huber S, Gianolini ME, Pala M, Licona-Limon $\mathrm{P}$, et al. Coexpression of CD49b and LAG-3 identifies human and mouse $\mathrm{T}$ regulatory type 1 cells. Nat Med. (2013) 19:739-46. doi: 10.1038/ nm.3179

30. Bobadilla S, Sunseri N, Landau NR. Efficient transduction of myeloid cells by an HIV-1-derived lentiviral vector that packages the Vpx accessory protein. Gene Ther. (2013) 20:514-20. doi: 10.1038/gt.2012.61

31. Locafaro G, Andolfi G, Russo F, Cesana L, Spinelli A, Camisa B, et al. IL-10-engineered human CD4+ Tr1 cells eliminate myeloid leukemia in an HLA class i-dependent mechanism. Mol Ther. (2017) 25:225469. doi: 10.1016/j.ymthe.2017.06.029

32. Gregori S, Tomasoni D, Pacciani V, Scirpoli M, Battaglia M, Magnani CF, et al. Differentiation of type $1 \mathrm{~T}$ regulatory cells $(\mathrm{Tr} 1)$ by tolerogenic DC-10 requires the IL-10-dependent ILT4/HLA-G pathway. Blood. (2010) 116:93544. doi: 10.1182/blood-2009-07-234872

33. Comi M, Avancini D, Santoni de Sio F, Villa M, Uyeda MJ, Floris M, et al. Coexpression of CD163 and CD141 identifies human circulating IL10-producing dendritic cells (DC-10). Cell Mol Immunol. (2020) 17:95107. doi: 10.1038/s41423-019-0218-0

34. Schülke S. Induction of interleukin-10 producing dendritic cells as a tool to suppress allergen-specific T helper 2 responses. Front Immunol. (2018) 9:455. doi: 10.3389/fimmu.2018.00455.

35. Henry E, Desmet CJ, Garzé V, Fiévez L, Bedoret D, Heirman C, et al. Dendritic cells genetically engineered to express IL-10 induce long-lasting antigenspecific tolerance in experimental asthma. J Immunol. (2008) 181:723042. doi: 10.4049/jimmunol.181.10.7230

36. Besche V, Wiechmann N, Castor T, Trojandt S, Höhn Y, Kunkel H, et al. Dendritic cells lentivirally engineered to overexpress interleukin-10 inhibit contact hypersensitivity responses, despite their partial activation induced by transduction-associated physical stress. J Gene Med. (2010) 12:23143. doi: $10.1002 /$ jgm. 1436
37. Wan J, Huang F, Hao S, Hu W, Liu C, Zhang W, et al. Interleukin10 gene-modified dendritic cell-induced type 1 regulatory $\mathrm{T}$ cells induce transplant-tolerance and impede graft versus host disease after allogeneic stem cell transplantation. Cell Physiol Biochem. (2017) 43:353-66. doi: 10.1159/000480415

38. Abdi K, Singh NJ, Matzinger P, Arnold TD, Niaudet C, Pang M-F, et al. Comparative transcriptional and functional profiling defines conserved programs of intestinal DC differentiation in humans and mice. Nat Immunol. (2014) 15:98-108. doi: 10.1038/ni.2768

39. Steinbrink K, Wölfl M, Jonuleit H, Knop J, Enk AH. Induction of tolerance by IL-10-treated dendritic cells. J Immunol. (1997) 159:4772-80.

40. Steinbrink K, Graulich E, Kubsch S, Knop J, Enk AH. CD4+ and CD8+ anergic $\mathrm{T}$ cells induced by interleukin-10-treated human dendritic cells display antigen-specific suppressor activity. Blood. (2002) 99:246876. doi: 10.1182/blood.V99.7.2468

41. Amodio G, Comi M, Tomasoni D, Gianolini ME, Rizzo R, Lemaoult J, et al. HLA-G expression levels influence the tolerogenic activity of human DC-10. Haematologica. (2015) 100:548-7. doi: 10.3324/haematol.2014.113803

42. Rossetti M, Gregori S, Roncarolo MG. Granulocyte-colony stimulating factor drives the in vitro differentiation of human dendritic cells that induce anergy in naïve T cells. Eur J Immunol. (2010) 40:3097106. doi: 10.1002/eji.201040659

43. Ezzelarab M, Thomson AW. Tolerogenic dendritic cells and their role in transplantation. Semin. Immunol. (2011) 23:25263. doi: 10.1016/j.smim.2011.06.007

44. Marín E, Cuturi MC, Moreau A. Tolerogenic dendritic cells in solid organ transplantation: Where do we stand? Front. Immunol. (2018) 9:274. doi: 10.3389/fimmu.2018.00274

45. Obregon C, Kumar R, Pascual MA, Vassalli G, Golshayan D. Update on dendritic cell-induced immunological and clinical tolerance. Front. Immunol. (2017) 8:514. doi: 10.3389/fimmu.2017.01514

46. Thomson AW, Metes DM, Ezzelarab MB, Raïch-Regué D. Regulatory dendritic cells for human organ transplantation. Transplant Rev. (2019) 33:130-6. doi: 10.1016/j.trre.2019. 05.001

47. Reichardt W, Dürr C, von Elverfeldt D, Jüttner E, Gerlach U V., Yamada $\mathrm{M}$, et al. Impact of mammalian target of rapamycin inhibition on lymphoid homing and tolerogenic function of nanoparticle-labeled dendritic cells following allogeneic hematopoietic cell transplantation. J Immunol. (2008) 181:4770-9. doi: 10.4049/jimmunol.181.7.4770

48. Chorny A, Gonzalez-Rey E, Fernandez-Martin A, Ganea D, Delgado M. Vasoactive intestinal peptide induces regulatory dendritic cells that prevent acute graft-versus-host disease while maintaining the graft-versustumor response. Blood. (2006) 107:3787-3794. doi: 10.1182/blood-200511-4495

49. Reddy P, Sun Y, Toubai T, Duran-Struuck R, Clouthier SG, Weisiger $\mathrm{E}$, et al. Histone deacetylase inhibition modulates indoleamine 2,3dioxygenase-dependent DC functions and regulates experimental graft-versus-host disease in mice. J Clin Invest. (2008) doi: 10.1172/jci 34712

Conflict of Interest: The authors declare that the research was conducted in the absence of any commercial or financial relationships that could be construed as a potential conflict of interest.

Copyright (c) 2020 Comi, Amodio, Passeri, Fortunato, Santoni de Sio, Andolfi, Kajaste-Rudnitski, Russo, Cesana and Gregori. This is an open-access article distributed under the terms of the Creative Commons Attribution License (CC BY). The use, distribution or reproduction in other forums is permitted, provided the original author(s) and the copyright owner(s) are credited and that the original publication in this journal is cited, in accordance with accepted academic practice. No use, distribution or reproduction is permitted which does not comply with these terms. 